\title{
Executive Privilege and Congressional Investigatory Power
}

\section{Bernard Schwartz*}

"Nothing ever becomes real," says Keats, "till it is experienced-even a proverb is no proverb to you till your life has illustrated it." This is as true in the law as it is in other areas of life. One may be familiar with, and even expert in, a particular branch of the law. His supposed expertise will, however, be more or less a matter of academic theory until he is personally affected by the operation of that branch in practice.

In recent years, the present writer has become deeply concerned with the subject of so-called "executive privilege"-i.e., the power of the Government to withhold information from the public, the courts, and the Congress. I had both written on the subject $t^{1}$ and testified with regard to it as a member of an invited panel of legal experts before a congressional committee. ${ }^{2}$ My own views on the matter were clearly opposed to those of the extreme proponents of executive privilege "... the overriding danger," I declared in my testimony just referred to, "is ... the vesting of unfettered discretion in the executive to surround with secrecy all its activities." 3

But it was not until I was personally confronted with the problem of securing access to the files of government agencies that I was really able to appreciate what executive privilege means in practice. During 1957, I came up against that problem in my capacity as chief counsel and staff director of the House subcommittee investigating the federal regulatory agencies. Representatives of the subcommittee staff working in the Civil Aeronautics Board had, on September 13, 1957, in accordance with my instructions, asked for the files in certain cases decided by the Board. It was not until September 30 that the $\mathrm{CAB}$ responded to this request. It did so by a staff notice directing its employees to withhold certain categories of documents from the subcommittee staff. ${ }^{4}$ More than that, the Board

* Professor of Law, New York University.

${ }^{1}$ Schwartz, Estoppel and Crown Privilege in English Administrative Law, 55 MIcH. L. Rev. 27 (1956); Schwartz, AN Introduction to AMIERICAN AdMINISTRative Law, ch. 10 (1958).

2 Hearings on Availability of Information from Federal Departments and Agencies, Before a Subcommittee of the House Committee on Government Operations, 84th Cong., 2d Sess., pt. 3, 451-66 (1956).

3 Id. at 465.

4 Civil Aeronautics Board, Staff Notice No. 333, September 30, 1957, which provided that:

(a) The personal files of the Board members shall not be available for inspection;

(b) Security classified materials and other materials held confidential under sections 1104, 902 (f), 18 U.S.C. 1905 , or applicable executive orders shall be permitted to be inspected or 
asserted the right, in itself, to "screen" its files in advance of their examination by the subcommittee staff and to determine in its discretion what documents should be made available. ${ }^{5}$

To say that one confronted with assertions of executive privilege feels a sense of sheer frustration is gross understatement. In my case, it was utterly impossible to carry out a full investigation into the operation of an agency like the $C A B$ without complete access to its files and records. Said the chairman of the House subcommittee, "The Board's attempt to place an Iron Curtain between the subcommittee and the very materials it has been specifically created to investigate would, if left unchallenged, utterly frustrate the study authorized by the House of Representatives."

The same frustration is felt by any lawyer who is confronted by executive privilege in his practice. Consider, for example, the situation of counsel for plaintiff in a recent federal case. ${ }^{7}$ Plaintiff brought an action against the United States, alleging that his decedent had died while in an Army hospital "as the result of negligence and carelessness of defendant, through its agents, servants, and employees, acting within the scope of their employment." Plaintiff then moved for the production of the hospital records and reports relating to his decedent. The Government filed a claim of privilege on the ground that these documents were "privileged" and "confidential" since "they relate to the internal management of the Department of the Army." In a case like this, if the claim of executive privilege is valid, plaintiff's counsel may well be in a helpless position. Without the relevant hospi-

their contents divulged only upon permission of the security officer or the Board as to security classified materials, and upon permission of the Board as to the other enumerated materials;

(c) Communications and memoranda between Board members, and between Board members and their assistants relating to matters acted on by the Board, and the statements made by Board members in the course of their dehberations, shall not be permitted to be inspected nor shall their contents be divulged:

(d) Communications not heretofore made public between the Board or its members or staff, on the one hand, and the President, his immediate staff, the State Department, and other executive departments and Government agencies, on the other, and relating to section 801 and 802 matters shall not be permitted to be inspected nor shall their contents be divulged except on permission from the White House or the department or agency involved;

(e) Other nonpublic comnunications between the Board, its members, and its staff, on the one hand, and other departments and agencies of the Government, on the other, will be permitted to be inspected or their contents divulged only upon permission from such department or agency, or, in the event permission is refused, upon order of the Board.

- Ibid., providing "that the representative not be permitted to inspect at will nonpublic or internal files in either pending or closed cases."

6 Letter of Morgan M. Moulder, Chairman, House Jegislative Oversight Subcommittee, to James R. Durfee, Chairman, Civil Aeronautics Board, October 3, 195\%. For a discussion of the CAB's refusal to give the Oversight staff full access to its files, see ScHwarTz, The Professor AND THE COMmISsions 67 et seq (1959).

7 Barclay v. United States, Civil No. 4422-50, D.D.C., June 15, 1950. The case is discussed in Mitchell, Government Secrecy in Theory and Practice: "Rules and Regulations" as an Autonomous Screen, 58 ColuM. L. REv, 199, 201 (1958). 
tal reports and records, how can he prove his claim that decedent's death was caused by defendant's negligence? ${ }^{8}$

The important thing to determine, of course, is whether the claims of government power to withhold information are valid. In the present article, emphasis will be placed on the asserted power of the executive to refuse to divulge information to the Congress. This aspect of the problem of privilege is, in my opinion, the most important in a system in which such a significant role is played by congressional investigations. It is also that aspect with which I am most familiar personally because of my own attempts to secure pertinent files and records from the $\mathrm{CAB}$ and the other federal regulatory agencies.

\section{Executive Claims}

Not surprisingly perhaps, there has been a plethora of Attorney General ipse dixits which have invariably supported the claims of the executive to withhold information. ${ }^{9}$ The most recent such statement by the Government's chief legal officer was that made by Attorney General Rogers before a Senate subcommittee in 1958. According to him, "in response to congressional requests for documents, the Executive should exercise a discretion as to whether their production would serve a public good or would be contrary to public interest." ${ }^{10}$ In the Attorney General's view, the question of what information should be disclosed to the Congress is one that is wholly within the discretion of the executive: "only the President can make the determination as to disclosure."11

Even more extreme was the claim of executive privilege made by $\mathrm{Mr}$. Rogers' predecessor. In a memorandum to the President of May 17, 1954, Attorney General Brownell asserted categorically that "our Presidents have established ... that they and members of their Cabinets and other heads of executive departments lave an undoubted privilege and discretion to keep confidential, in the public interest, papers and information which require secrecy."12 Moreover, he went on, "the President and the heads of departments have an uncontrolled discretion to withhold the information and papers in the public interest." 13

Mr. Brownell's claim of unfettered discretion in the executive to with-

\footnotetext{
${ }^{8}$ For a comparable recent English case, see Broome v. Broome, [1955] 2 W.L.R. 401, discussed in Schwartz, Estoppel and Crown Privilege in English Administrative Law, 55 MICE. L. REv. 27, 56-60 (1956).

${ }^{\circ}$ See Bishop, The Executive's Right of Privacy: An Unresolved Constitutional Question, 66 YaLE L.J. 477, 483 (1957).

10 Rogers, Constitutional Law: The Papers of the Executive Branch, 44 A.B.A.J. 941, 944 (1958).

11 Id. at 1012 .

12 N.X. Times, May 18, 1954, p. 24, col. 2, reprinted as Brownell, Memorandism on Separation of Powers, 14 FED. B.J. 73 (1954).

${ }^{13} \mathrm{Id}$. at 74. (Emphasis added.)
} 
hold was called forth by the Army-McCarthy controversy. During it, on May 17, 1954, the President sent a letter to the Secretary of Defense in which he instructed that official not to disclose any internal departmental communications to the relevant Senate subcommittee. Attorney General Brownell's memorandum was issued in support of the President's letter.

The President's letter of May 17, 1954 pushed the privilege claim very far. According to it,

Because it is essential to efficient and effective administration that employees of the Executive Branch be in a position to be completely candid in advising with each other on official matters, and because it is not in the public interest that any of their conversations or communications, or any documents or reproductions, concerning such advice be disclosed, you will instruct employees of your Department that in all of their appearances before the Subcommittee of the Senate Committee on Government Operations regarding the inquiry now before it they are not to testify to any such conversations or communications or to produce any such documents or reproductions. ${ }^{14}$

Hard cases, goes the old saw, make bad law. But legal claims made under severe stress may make even worse law. The extreme claim of privilege made $i m$ the President's letter can perhaps be understood as a reaction to the equally extreme attacks of the late jumior Senator from Wisconsin. And it was the threat of McCarthyism, too, that led the press to ignore the dangers inherent in the President's claim and to concentrate instead upon the President's rebuff to what the Washington Post termed "governmentby-McCarthy." 15

In actuality, the President's letter of May 17, 1954 stretches the claim of executive privilege to the breaking point. Even a writer generally friendly to the claims of executive privilege concedes with regard to the principle of immunity fron disclosure claimed in the President's letter: "the general principle was, in my opinion, stated too broadly. A very large part of administrative work consists of advice and communication between and among government officials. If President Eisenhower's directive were applied generally in line with its literal and sweeping language, congressional committees would frequently be shut off from access to documents to which they are clearly entitled by tradition, common sense, and good governmental practice."16 According to the President's letter, all internal communications within a department or agency are privileged from disclosure to the Congress. It needs little reflection to realize that, if such a position becomes established in law and practice, the investigatory power of the Congress

14 The President's letter is reprinted in Rogers, Constitutional Law: The Papers of the Executive Branch, 44 A.B.A.J. 941, 1009 (1958).

15 Editorial, May 20, 1954, quoted, id. at 1010.

16 TaYLoR, Grand Inquest 133 (1955). 
over the operations of government agencies will become completely meffective.

\section{Privilege and Sovereign Immunity}

What is the foundation for the executive privilege so broadly asserted by its advocates? There is little doubt that the claim of executive immunity in this respect is an anachronistic survival of monarchical privilege, derived from the basic doctrine of sovereign immunity-perhaps the most incongruous of all doctrines in our public law. Under it, the government is placed in a privileged position of immunity from the principles of law which are bimding upon the ordinary citizen, unless it expressly consents to be bound by such primciples. In Anglo-American law the infallibility attributed to the King in the days when he was personally sovereign has been more recently recognized in the government, which the Crown now merely personifies. Thus, even today, and even in the American democracy, a basic principle of public law is that the King can do no wrong. ${ }^{17}$

That the doctrine of sovereign immunity is mconsistent with the rule of law has long been recognized. "Whether this immunity is an absolute survival of the monarchial privilege, or is a manifestation merely of power, or rests on abstract logical grounds, ... it undoubtedly runs counter to modern democratic notions of the moral responsibility of the State," Justice Frankfurter has asserted. ${ }^{18}$ Sovereign immunity has tended to dualize our public law by treating cases against the state as wholly distinct from those governed by the ordinary law, to be dealt with on wholly different primciples. Legal concepts have not been apphicable, without the state's express consent, to cases governed by the sovereign immunity doctrine. The result has been a system of public law dualist in essence. Different rules apply to cases in which the government is a party; different consequences flow from acts of the government; and cases in which the responsibility of the government is at issue are removed from the cognizance of the courts. In such a system the government has, in effect, been placed upon a higher plane than the individual, with complete immunity given to its acts qua state acts.

Criticism of the sovereign immunity doctrine has, until now, been focused almost entirely upon its effects on the law of public tort and contract liability. It has, not unnaturally, been assumed that with the enactment of statutes like the Federal Tort Claims Act of 1946 under which most of the sovereign's immunity to suit has been waived, the lacuna in the rule of law ${ }^{19}$ caused by the sovereign immunity doctrine has been completely filled. What is not generally realized, lowever, is that the doctrine of sovereign immunity

17 Davis, Administrative Law 797 (1951).

18 Dissenting, in Great Northern Ins. Co. v. Read, 322 U.S. 47, 59 (1944).

19 So characterized in Committee on Ministers' Powers, Report, Cam. No. 4060, at 112 (1932). 
is a pervasive one, whose effect in Anglo-American public law has not been limited to the field of public tort and contract liability.

The privilege of the executive to withhold information is an aspect of sovereign immunity that remains unaffected by laws like the Torts Claims Act. In the pretensions of those who espouse executive privilege, the infallibility recognized in the King in the days when he was personally sovereign in England has been attributed to the President in our own system. Indeed, if their claims are correct, it would indicate that the lacuna in the rule of law caused by the sovereign immunity doctrine still needs quite some filling. As far as the proponents of executive privilege are concerned, the King can still do no wrong.

\section{Separation of Powers}

Those who assert a privilege in the executive to withhold information from the Congress find their principal doctrinal support in the doctrine of the separation of powers. Said the President in his already-referred-to letter of May 17, 1954: "I direct this action so as to maintain the proper separation of powers between the Executive and Legislative Branches of the Government in accordance with my responsibilities and duties under the Constitution. This separation is vital."

The separation of powers was also strongly relied on by Attorney General Brownell, in his memorandum in support of the President's letter and in Attorney General Rogers' recent testimony before the Senate subcommittee. The separation doctrine, they say, makes the executive the absolute master of information originating with it; for the legislature or the courts to require the executive to divulge information would be for them to infringe upon the autonomy of a coordinate branch of government. "It is essential," declares Mr. Brownell's inemorandum, "that the persons entrusted with power in any one of these branches shall not be permitted to encroach upon the powers confided to the others, but that each shall be limited to the exercise of the powers appropriate to its own department and no other."20

Yet, unless we follow the extreme view that the separation of powers divides the branches of government into three watertight compartments, it would appear the Brownell criterion does not really help us in dealing with the problem of executive withholding of imformation. Each branch, declares the portion of the memorandum just quoted, "shall be limited to the exercise of the powers appropriate to its own department and no other." But this begs the question, as far as the problem at issue is concerned, for it does not in any way tell us to what "powers appropriate to its own department" the authority of the Congress is limited. The implication is that congressional authority is limited to the enactment of laws; in no other way

20 N.Y.Times, May 18, 1954, p.24, col.2, reprinted as Brownell, Memoranditm on Separation of Powers, 14 FED. B.J. 73 (1954). 
can it act. Such gratuitous interpretation of the powers of the Congress is, however, wholly out of line with modern theory and practice on the proper role of a legislative assembly in a democratic state.

As that organ of the federal government which alone is vested with the power to enact laws, the primary province of the Congress is, of course, to ' legislate. It would, nevertheless, be erroneous to think of the functions of a modern legislative assembly solely in terms of lawmaking. "The political philosopher of these days of self-government," wrote Woodrow Wilson in 1884, criticizing the extent to which the work of the Congress was then devoted almost exclusively to legislation, "has . . . something more than a doubt with which to gainsay the usefulness of a sovereign representative body which confines itself to legislation to the exclusion of all other functions. ... Quite as important as legislation is vigilant oversight of administration; and even more important than legislation is the instruction and guidance in political affairs which the people might receive from a body which kept all national concerns suffused in a broad daylight of discussion. There is no similar legislature in existence which is so shut up to the business of lawmaking as is our Congress."21

It cannot be denied that there is a great deal of truth in this criticism of a representative assembly whose time is spent solely in passing laws. Important though the legislative function itself may be, a legislative body is hardly worthy of the title of Congress or Parliament if it merely grinds out legislation as a sausage maker grmds out sausages.

Under contemporary conditions, the national legislature is the one great forum of expression which can be reached by the individual citizen. His congressman is the one national official who is in contact with, and responsible to, a relatively small local area. It is through its representative in the national assembly alone that the locality is normally able to make its views heard on the national level.

But the legislative body is more than a "committee of grievances" where those represented can ventilate their opinions and complaints. It is even more important as a molder than as a receptacle of public opinion. Its job in this respect is to enlighten and educate by ensuring adequate discussion of the important issues before the nation. The debate in the legislature should clarify those issues and enable the nation intelligently to support or oppose the position finally taken in the two Houses.

As consequential as its position as the forum of the nation is the modern legislature's role as overseer of the administration. It is almost a truism that the critical point of present-day governmental developments is the consistent growth of executive authority. The type of regulatory activity which contemporary public opinion requires the state to engage in can, as a prac-

21 Wirson, Congressional Governarent in the United States 295, 297 (10th ed, 1894). 
tical matter, be carried on only by the executive branch. For its officers to operate effectively in the administration of the vast regulatory and social service schemes undertaken by the state, they must be vested with large areas of discretionary authority. The delegation of powers to the executive in a particular field does not, however, relieve the legislature of responsibility over that field. The Congress does not really get rid of a subject by delegating powers to the executive. The consistent transfer of authority to the administration only increases the difficulty, from the point of view of the effective working of representative democracy.

"Initially," states Dr. Griffith, the Director of the Legislative Reference Service, "the pressure may have been on Congress for legislation (or upon the President as party leader); ultimately, the highly intricate task of continuously intervening in the economic order has by virtue of legislative authorization and delegation of power become the task of a bureau or commission. Here is a transfer in the equilibrium of power and effectiveness, and the transfer is away from the operative significance of representative government and toward the bureaucratic ascendancy of the technically competent." 22 If the trend toward bureaucratic predominance is successfully to be resisted, the legislature must not surrender control as it has delegated power. Unless the exercise of the authority delegated to him is closely supervised by the elected representatives of the people, the administrator is, in effect, placed in a position of almost complete irresponsibility. It is this which makes oversight of the executive so important a part of the job of a modern legislature.

It may thus be seen that the exercise of its authority to enact laws is but part of the work of a legislature like the Congress. In terms which sum up what has been said above, an acute student of government stated over a decade ago:

The primary tasks of modern legislative assemblies may be arranged in four classes. First, but not necessarily foremost, is the function of lawmaking. At least equally important is the responsibility of supervising the Executive; the Legislature in this role may be compared to a board of directors of a business corporation which at least theoretically, endeavors to hold "administrative officers to a due accountability for the manner in which they perform their duties." A third legislative office, broad in its implications, involves activities as an organ of public opinion; a lawmaking body may serve as a national forum for the expression, formulation, or molding of opinion. The remaining function, which may be termed membership, concerns im. ternal matters especially the judging of the qualifications and conduct of the delegates to the Legislative Assembly. ${ }^{23}$

The proper exercise of the congressional functions just outlined presupposes the existence of an informed judgnient on the part of the members 
of the two Houses. As President Truman aptly declared over 10 years ago, "an informed Congress is a wise Congress; an uninformed Congress surely will forfeit a large portion of the respect and confidence of the people." ${ }^{24}$ Informed judgment on the part of the members of Congress cannot normally exist, as a practical matter, if they do not possess sufficient information about the conditions which their acts are intended to affect. Nor is adequate mformation usually available within the Congress itself alone. The knowledge possessed by its members must necessarily be supplemented by that obtained from outside sources.

As strong a statement as any upon the right of the Congress to obtain the information necessary for informed exercise of its functions is that made for a unanimous Supreme Court by Mr. Justice Van Devanter in the famous case of McGrain v. Daugherty.

We are of the opinion that the power of inquiry-with process to enforce it-is an essential and appropriate auxiliary to the legislative function.... A legislative body cannot legislate wisely or effectively in the absence of information respecting the conditions which the legislation is intended to affect or change; and where the legislative body does not itself possess the requisite information-which not infrequently is true-recourse must be had to others who do possess it. ... Thus there is ample warrant for thinking, as we do, that the constitutional provisions which commit the legislative function to the two houses are intended to include this attribute to the end that the function may be effectively exercised. ${ }^{25}$

In Justice Van Devanter's view, the power to obtain information is included in the grant of legislative power to the Congress in article I of the Constitution. But, if this view is correct-and it is supported by the authority of the entire Supreme Court-it refutes the constitutional basis upon which Attorney General Brownell's inemorandum, already referred to, purports to rest. Even if the separation of powers doctrine requires, as $\mathrm{Mr}$. Brownell asserts, that each branch shall be limited to the powers appropriate to its own departnient, that does not affect the congressional right to information. For McGrain v. Daugherty holds that the authority to obtain information is an essential attribute of the powers appropriate to the legislative department.

Indeed, if the separation of powers has anything to tell us on the subject under discussion, it is that the Congress has the right to obtain information from any source- even from officials of departments and agencies in the executive branch. In the Ulited States there is, unlike the situation which prevails in a parliamentary system such as that in Britain, a clear separation between the legislative and executive branches. It is this very separa-

24 Hearings Pursuant to H. Con. Res. 18 Before the Joint Committee on The Organization of Congress, 79th Cong., 1st Sess., pt. 4, at 908 n.3 (1945).

25273 U.S. 135, 174-75 (1927). 
tion that makes the congressional right to obtain information from the executive so essential, if the functions of the Congress as the elected representatives of the people are adequately to be carried out. The absence of close rapports between the legislative and executive branches in this country, comparable to those which exist under a parliamentary system, and the nonexistence in the Congress of an institution such as the British question period have perforce made reliance by the Congress upon its right to obtain information from the executive essential, if it is intelligently to perform its legislative tasks. Unless the Congress possesses the right to obtain executive information, its power of oversight of administration in a system such as ours becomes a power devoid of most of its practical content, since it depends for its effectiveness soleky upon information parceled out ex gratia by the executive.

\section{Case-Law}

Those who assert that the law is settled in favor of an unlimited right in the executive to withhold information from the Congress really do so out of an excess of executive zeal but without any real basis in fact-or in law, for that matter. Perhaps the leading such assertion is that contained in the Brownell memorandum in support of the President's letter of May 17, 1954. It should, in the first place, be noted, as a recent article points out, that most of this memorandum "was lifted almost word for word from a law review article which had appeared some years previously . . . ."28

Though Attorney General Brownell, parroting the article referred to, starts with the categorical assertion that "courts have umiformly held that the President and the heads of departments have an uncontrolled discretion to withhold [from Congress] the information and papers in the public interest," ${ }^{27}$ neither his memorandum nor the article cite any cases in support. Indeed, according to one writer, this assertion is "remarkable and inexact."28 For the Attorney General's real source of authority to be a law review writer (himself a Department of Justice functionary) ${ }^{20}$ who cites no relevant judicial precedent is most disturbing. Once upon a time, legislative power was sought to be drastically restricted by the authority of the Crown. But here we have a case where an essential function of the elected representatives of the people is sought to be emasculated, not by royal proclamation, but by the prerogative of one Herman Wolkinson.

${ }^{26}$ Bishop, The Executive's Right of Privacy: An Unresolved Constituttional Question, 66 YaLE L.J. 47\%, 478 (1957). The article referred to is Wolkinson, Demands of Congressional Commitlees for Executive Papers, 10 FED. B.J. 103, 223, 319 (1949).

27 N.Y. Times, May 18, 1954, p. 24, col.2, reprinted as Brownell, Memoranditm on Separation of Powers, 14 FED. B.J. 73, 74 (1954).

28 Bishop, The Executive's Right of Privacy: An Unresolved Constitutional Question, 66 YALE L.J. 477,478 (1957).

29 The Wolkinson article, note 26 supra, lists its author as "Attorney, Department of Justice." 
The Brownell memorandum, as already noted, asserts that courts have uniformily upheld the doctrine of executive privilege vis-a-vis the Congress. This assertion is all the more remarkable in that it is utterly unsupported by any cited case. In actuality, there is no authority in decisions of the Supreme Court for the withholding of information from the Congress by the executive. The cases usually cited as sustaining executive claims in this connection are Boske v. Comingore ${ }^{30}$ and United States ex rel. Touhy v. Ragen. ${ }^{31}$

But those cases held only that the head of an executive department can lawfully centralize in himself the authority to determine whether documents of the department may be released for use of persons outside the department. The decisions in both cases were confined to this narrow issue. This is shown clearly by the Court's conclusion in the Boske opinion, where it says, "In our opinion the Secretary, under the regulations as to the custody, use and preservation of the records, papers and property appertaining to the business of his Department, may take from a subordinate, such as a collector, all discretion as to permitting the records in his custody to be used for any other purpose than the collection of the revenue, and reserve for his own determination all matters of that character." 32

As Mr. Justice Frankfurter emphasized, in concurring in the Touhy case, "There is not a hint in the Boske opinion that the Government can shut off an appropriate judicial demand for such papers." 33

In fact, as the learned Justice pointed out, the question of the immunity of the Attorney General from the duty to disclose information in his department's possession was not before the Court: "Specifically, the decision and opimion in this case cannot afford a basis for a future suggestion that the Attorney General can forbid every subordinate who is capable of being served by process fronl producing relevant documents and later contest a requirement upon him to produce on the ground that procedurally he cannot be reached. In joining the Court's opinion I assume the contrary-that the Attorney General can be reached by legal process." 34

The Boske and Touhy cases are thus not relevant to the question of executive withholding of information, and certainly not to the congressional right to information. The Supreme Court held only that a department head can forbid his subordinates from disclosing information. But to assume from this that the department head himself is able conclusively to determine whether information should be withheld from Congress or the courts is to

30177 U.S. 459 (1900).

31340 U.S. 462 (1951).

32177 U.S. at 470.

38340 U.S. at 472.

34 Ibid. 
jump to a conclusion which the Supreme Court tells us expressly ${ }^{35}$ it was not called upon to reach. As Justice Frankfurter pithily expresses it: "To hold now that the Attorney General is empowered to forbid his subordinates, though within a court's jurisdiction, to produce documents and to hold later that the Attorney General himself cannot in any event be procedurally reached would be to apply a fox-hunting theory of justice that ought to make Bentham's skeleton rattle." 36

What has been said of the Supreme Court decisions in Boske and Touhy is true also of the lower court cases usually cited by exponents of executive privilege, especially Ex parte Sackett. ${ }^{37}$ Among the most recent of these cases is Appeal of Securities and Exchange Commission and William $H$. Timbers. ${ }^{38}$ It is true that the court in Timbers went somewhat further than merely following the Boske and Touhy cases. There is some dicta in the court's opinion indicating that there may be some basis for claiming executive privilege for certain agency documents in private litigation in a court. Yet, it should be emphasized that the Timbers court clearly based its language upon the fact that this was a private case in court. As Mr. Timbers himself has put it, in a recent article, "the appellate court stated, the trial judge 'overstepped appropriate judicial bounds'; for it was not his function to conduct an investigation of the Commission's performance of its official responsibilities." ${ }^{39}$ But it is emphatically the function of the Congress to conduct just such an investigation of the performance by agencies like the SEC of their official responsibilities. In making such an investigation the Congress is not, as will be shown, restricted by the limitations that apply to judicial powers of inquiry.

As against the Boske and Touky cases, which do not really support the broad claitns of executive privilege usually based upon them, even in courtroom cases, there is a veritable mass of contrary judicial authority, which resoundingly repudiates the concept of privilege. It is literally amazing that the Attorney General and other proponents of executive privilege do not even bother to cite these cases. Either they are ignorant of the contrary precedents-certaiuly most disturbing, if true, of the Government's highest legal officer - or they have cited only the cases in support of their claims.

In the first place, it should be noted that John Henry Wigmore, the dean

35 Id. at 469 .

38 Id. at 473 .

3774 F.2d 922 (9th Cir. 1935).

38226 F.2d 501 (6th Cir. 1955). See Hearings Before the Subcommittee on Availability of Information from Federal. Departments and Agencies of the House Committee on Government Operations, 84th Cong., 2d Sess., pt. 12, 2733 (1956).

39 Timbers \& Cohen, Demands of Litigants for Government Information, 18 U. PITT. L. REv. 687, 728 (1957). The same is true of the more recent: case of Kaiser Aluminum \& Chemical Corp. v. United States, 157 F. Supp. 939 (Ct. Cl. 195\&). 
of the American law on the subject, strenuously opposed the whole concept of executive privilege. Much of volume 8 of his Treatise on Evidence is devoted to a demolition of the claims of those who assert the doctrine of privilege. Wigmore is particularly caustic with regard to the argument that, in such cases, the public interest against disclosure must be considered paramount to the individual interest of private litigants, declaring: "As if the public interest were not involved $\mathrm{m}$ the administraiton of justicel As if the denial of justice to a single suitor were not as inucl a public inquiry as is the disclosure of any official record! When justice is at stake, the appeal to the necessities of the public mterest on the other side is of no superior weight. 'Necessity,' as Joshua Evans said, 'is always a suspicious argument, and ever wanting to the worst of causes'."40

It is interesting to note that a foreign commentator, referrmg to Dean Wigmore's strictures says, "his remarks, we think, are ... a reflection upon the absolutisin of the American executive . .." Suggestively enough, Mr. Wolkinson, whose article has already been shown to be the basis of much of the language and supposed law in Attorney General Brownell's memorandum, cites in detail every text writer (no matter how obscure) who may possibly be deemed to support executive privilege. But he relegates Wigmore to only two cryptic sentences. ${ }^{42}$

That Wigmore on the subject is, lowever, clearly to be preferred to Wolkinson is shown by Crosby v. Pacific S.S. Lines. ${ }^{43}$ The court there expressly relied upon Wigmore in rejecting a claim of official privilege. The fact pattern was somewhat unusual. The case arose out of a civil bankruptcy proceeding. A witness, who was an official of the British Mimistry of Supply (not a party to the case), declined, on cross-examination, to produce internal correspondence and memorandums of the Ministry, on the ground that they were "confidential" documents belonging to the British Government. The case is relevant for our purpose because the federal court specifically stated that it would treat the British Ministry by the same standard as would "apply to a similar department of government here." ${ }^{44}$ And the court concluded that there was no valid privilege in a case like this, saying: "It is enough to say that for one to claim a privilege, he must make a showing that he is entitled to one, and that no such slowing, in our opinion, was made here. ${ }^{45}$ In other words, according to the instant court, an executive de-

408 WIGMORE, EVIDENCE 790 (3d ed. 1940).

41 Note, 58 L.Q. REv. 31, 34 (1942).

42 Wolkinson, Demands of Congressional Committees for Executive Papers, 10 FED. B.J.

103, 334, 335 (1949).

43133 F.2d 470 (9th Cir.), cert. denied, 319 U.S. 752 (1943).

44 Id. at 475 .

45 Ibid. 
partment cannot refuse to disclose merely by raising a claim of official privelege.

Just as important is the fact that the court strongly emphasized that it is the function of the court, not the executive, to determine what evidence is privileged. An attempt was made to bring the case under a California statute applicable "when the public interest would suffer by disclosure." 40 But, asked the court, "Does this nean that [the executive official] is the final authority on that point? All reason says that the question is one for the court to determine." ${ }^{47}$ This is wholly contrary to the assertions of Attorney Generals Brownell and Rogers, already referred to, that it is for the executive itself to determine what matters nust remain concealed in its departmental pigeonholes.

Similarly, in Reynolds $v$. United States, ${ }^{48}$ the court rejected a broad claim of executive privilege, holding categorically that it was the court, not the executive, who had the last word on the question. The Suprene Court, in reversing, ${ }^{49}$ expressly declined to consider the broad proposition of privilege raised by the Governnient, but decided instead on other grounds. Yet, it is important to note that, even so, the highest Court was careful to state that the determination of privilege must be made by the court, declaring expressly, "Judicial control over the evidence in a case cannot be abdicated to the caprice of executive officers."

Nor are these the only cases rejecting the extreme claim of executive privilege in courtroom proceedings. In United States v. Certain Parcels of Land, ${ }^{51}$ a condemnation action by the Government, the defendant sought certain internal files of the Department of Justice. Of course, the Government was quick to clain privilege; but its claim was not sustained by the court. The court's language should be quite thought provoking to those who uncritically accept the extrene arguments for executive privilege:

In short the Government's claim of immunity under the Attorney General's regulations does not rest upon any privilege 'established in the law of evidence.' ... The sole ground for the claim is that the documents are "confidential reports in Department of Justice files": the Government's theory being, as stated before, that "reports in the Department of Justice files" are privileged because made confidential by Order No. 3229 (Revised).

Clearly there is no such privilege known to the law of evidence. The most then that can be said for the Government's position is that there is a general public policy agamst unnecessary disclosure of files of the executive branches of the Government. However, this policy may readily be out-

${ }^{46}$ Car. Code Crv. Proc. $\$ 1881$ (5).

47133 F.2d at 475.

48192 F.2d 987 (3d Cir. 1951), reversed, 345 U.S. 1 (1953).

49 United States v. Reynolds, 345 U.S. 1 (1953).

50 Id. at 9-10.

5115 F.R.D. 224 (S.D. Cal. 1953). 
weighed by the public interest in disclosure when such files contain documents of evidentiary value in a court of justice..$^{52}$

Another case along this line is Zimmerman v. Poindexter, ${ }^{53}$ where, in a civil suit for wrongful imprisonment, the plaintiff by subpena sought to get certain files from the Arny, including Federal Bureau of Investigation reports. The court there too rejected the claim that it was for the executive itself to determine what documents to withhold. According to the court, it itself had to make that determination: "We conclude by holding that to sustain the assertion of privilege of concealment under the specific situation before the court would be tantamount to abdicating an inherent judicial function of determining the facts upon which the admissibility of evidence in a case depends. This we cannot do." 54

Also of moment here is the line of criminal cases where executive privilege has been asserted. These cases have uniformly rejected the executive claims and have culminated in the recent decision of the Supreme Court in Jencks v. United States. ${ }^{55}$ In Jencks, the Court refused to recognize executive privilege to withhold Federal Bureau of Investigation files from the defendant, even without a showing on his part how the files sought were directly relevant to his defense. The need for justice, said the Court, is greater than any prejudice "attendant upon the possible disclosure of state secrets and other confidential infornation in the Government's possession." 56

It is recognized that there are many who do not agree with the Jencks decision and there there has, indeed, been enacted a law which seeks to correct its extreme effects. ${ }^{57}$ But can it seriously be contended that a Court which held that a private individual must be given access even to Federal Bureau of Investigation files would refuse to hold that the elected representatives of the people are entitled to at least the same access? Certainly, a tribunal which decided Jencks the way it did would be most unlikely to give free rein to the advocates of absolute executive privilege vis-a-vis the Congress.

\section{Statutes}

Executive departments and agencies have generally relied upon three statutes as empowering thein to refuse to divulge information in their pos-

52 Id. at 230. (Emphasis added.)

6374 F. Supp. 933 (D. Hawaii 1947).

64 Id. at 936. A more recent case rejecting privilege in the courts is Mitchell v. Bass, 252 F.2d 513 (8th Cir. 1958).

55353 U.S. 657 (1957).

60 Id. at 672 .

5718 U.S.C. $\$ 3500$ (d) (Supp. V, 1958). 
session. Do these statutes really furnish a legal basis for the executive claims in this field?

(a) 5 U.S.C. $\S 22 . .^{58}$

Until recently, the principal statute relied upon as authority for the executive withholding of information was a provision of title 5 , United States Code, section 22, under which: "The head of each department is authorized to prescribe regulations, not inconsistent with law, for the government of his department, the conduct of its officers and clerks, the distribution and performance of its business, and the custody, use, and preservation of the records, papers, and property appertaining to it."

In a claim of privilege made in 1955 in a federal court, the Acting Secretary of the Treasury stated that the discretion to withhold information is a general privilege belonging to the Government in consequence of the authority vested in the heads of the several departments, by title 5 , section 22 , to control the use of records and papers belonging to their respective departments. ${ }^{58}$

The Department of Justice in its answer to a questionnaire submitted by a House subcommittee cited United States ex rel. Touthy v. Ragen ${ }^{00}$ to support the proposition that title 5, section 22 authorizes executive withholding of information; ${ }^{81}$ but we have seen that the Court's decision in that case does no such thing. Both the Touhy case and Boske v. Comingore, ${ }^{02}$ hold only that the statute in question authorized a regulation centralizing the discretion of the department with regard to the disclosure of information in the department head. Neither case, as already shown, deals with the question of whether the department head himself is immune from process to compel him to disclose in a judicial proceeding information in the possession of his department. And neither case, of course, has anything directly to do with the claimed statutory right of the executive to withhold information from the Congress. Indeed, if Justice Frankfurter is correct in his conclusion in his concurring opinion in the Touhy case that the statute does not furnish the department head immunity from legal process, ${ }^{03}$ it follows clearly that that statute also does not confer on him any authority to withhold information from the Congress.

The statutory provision under discussion does not really bear on the executive power to withhold information from the Congress. It merely gives

58 REV. STAT. \& 161 (1875), 5 U.S.C. \& 22 (1952).

59 Overby v. U.S. Fidehty \& Guar. Co., 224 F 2 d 158, 160, n.2 (5th Cir. 1955).

60 See text at note 31 supra.

61 Repites from Federat Agencies to Questionnafee Suemitted by the Speciax SubCOMMITTEE ON GOVERNMENT INFORMATION OF THE HOUSE COMMCITTEE ON GOVERNMENT OpERATIONS, 84th Cong., 1st Sess., 312 (1955).

62 See text at note 30 supra.

03 See text at note 33 supra. 
department heads authority to regulate within their departments the way in which requests for information are to be dealt with-for example, by centralizing the authority to deal with such requests in the department head. It is thus a "housekeeping" statute and not a delegation of authority for withholding information.

This is even clearer today than it was even a few years ago, for, in 1958, the following sentence was added to title 5, section 22: "This section does not authorize withholding information from the public or limiting the availability of records to the public.. 364

\section{(b) Administrative Procedure Act. ${ }^{.5}$}

It has been asserted by some departments and agencies that section 3 (c) of the Administrative Procedure Act gives them authority to withhold information in their discretion.

Under that section, "Save as otherwise required by statute, matters of official record shall in accordance with published rule be made available to persons properly and directly concerned except information held confidential for good cause found."

As a starting point it seems shocking that a statute, one of whose primary purposes was to increase the availability of administrative information, should be used by departments and agencies as a source of authority for the withholding of information. Section 3 of the Administrative Procedure Act was intended to be an "open sesame" for the public into the mysteries of the executive branch. Yet it cannot be denied that, despite the act, there are still serious gaps in the field of executive information. In the words of the late Senator McCarran, there are still "detailed omissions which citizens and lawyers constantly find in their attempted pursuits of the maze of administrative procedures. . . ."60

That section 3(c) of the act should be interpreted by departments and agencies to restrict the disclosure of information may be paradoxical, but it must be admitted that the language of that section may justify the restrictive interpretation. Indeed, it can be said that the section is so circumscribed with exceptions and reservations as to defeat its very purpose as a requirement that executive information be disclosed. In the first place, there is the broad exception at the beginning of section 3 , making all its provisions-of course including this subdivision-inapplicable "to the extent that there is involved (1) any function of the United States requiring secrecy in the

6472 Stat. 547 (1958). See Mitchell, Government Secrecy in Theory and Practice: "Rules and Regulations" as an Autonomous Screen, 58 CoLvM. L. REv. 199, 207-08 (1958).

6560 Stat. 237 (1946), 5 U.S.C. $\$ \S 1001-11$ (1952).

$00 \mathrm{McCarran}$, Three Years of the Federal Administrative Procedure Act-A Study in Legislation, 38 GEO. L.J. 574, 576 (1950). 
public interest or (2) any matter relating solely to the internal management of an agency." It is not contended that some such exception to the public information section of the act is not necessary. One wonders, however, whether it is not too broadly drawn; under it, the departments and agencies can, if they wish, immumize any function from public inspection simply by asserting that the public interest requires it.

Section 3 (c) itself states it is not to apply where it is "otherwise required by statute." This takes cognizance of numerous specific statutory restrictions against disclosure of information. Thus, protection from disclosure is accorded trade secrets, processes, operations, style of work, or apparatus, and the identity, confidential statistical data, amount or source of any incoine, profits, losses, or expenditure of persons, firuns, partnerships, corporations, and associations, and this applies throughout all department and agencies. ${ }^{67}$ And individual agencies are required to keep confidential certain specific classes of records, for example, tax returns. ${ }^{68}$ These statutory exceptions represent an express judgment by the Congress against disclosure in specific cases.

More doubtful is the limitation in section 3(c) that information be made available only "to persons properly and directly concerned." Except where statutes expressly require secrecy, as in the protection of trade secrets and the like, all public records should be made available to the public at large. Even inore doubtful is the exception at the end of section 3(c) exempting disclosure of information "held confidential for good cause found." This enables departments and agencies to withhold practically all information which they do not see fit to disclose. It is, indeed, annazing how many agencies make use of this exception to treat all their files and records as confidential. ${ }^{69}$ Although they are supposed to exercise the discretion in individual cases, they adopt a broadside rule: all of our records should be confidential. This, of course, defeats the intent of the draftsmen of the Administrative Procedure Act.

What has just been said points to the conclusion that the Administrative Procedure Act should be ainended to make it clear that the qualifications in the law are not intended to enable agencies to withhold practically all inforination they do not see fit to disclose. It should be emphasized, nevertheless, that even if the unfortunate present wording of section 3(c) can be interpreted as conferring authority to withhold information from the public, the statute in question does not confer any authority for the withholding of information from the Congress. On that question, the Administration Procedure Act is irrelevant.

67 18 U.S.C. \$ 1905 (1952).

6853 Stat. 29 (1940), 26 U.S.C. \& 55 (1952).

${ }^{89}$ See chart III-F in part VI of the Hoover Commission Task Force Report on Legal Services and Procedure (unpublished 1955). 
(c) 18 U.S.C. $\$ 1905$

The third statute relied upon to justify the executive withholding of information is a part of the criminal law, namely, title 18, United States Code, section 1905, under which,

Whoever, being an officer or employee of the United States or of any department or agency thereof, publishes, divulges, dicloses, or makes known in any manner or to any extent not authorized by law any information coming to him in the course of his employment or official duties or by reason of any examination or imvestigation made by, or return, report or record inade to or filed with, such department or agency or officer or einployee thereof, which information concerns or relates to the trade secrets, processes, operations, style of work, or apparatus, or to the identity, confidential statistical data, amount or source of any income, profits, losses, or expenditures of any person, firm, partnership, corporation; or association; or permits any income return or copy thereof or any book containing any abstract or particulars thereof to be seen or examined by any person except as provided by law; shall be fined not more than $\$ 1,000$, or imprisoned not more than one year, or both; and shall be removed from office or employment. ${ }^{70}$

The emphasized portion of this stautory provision would appear to make its terms inapplicable to the subject under discussion. If an executive officer furnishes information to a congressional committee engaged in its constitutionally granted function of acquiring information to enable the Congress intelligntly to exercise its legislative powers, it would seem that he is not acting in a manner "not authorized by law." On the contrary, when he acts in response to congressional demand, his disclosure becomes authorized by law and he is immunized from prosecution under the statute.

This has been recognized by the Attorney General himself. In a 1953 opinion, it was decided that the authority conferred by statute to liquidate the assets of the Reconstruction Finance Corporation included by implication the authority to disclose borrowers' financial statements; hence, according to the Attorney General, disclosure in such case would be "authorized by law" and not prohibited under the statute. ${ }^{71}$ If this is true, the powers of investigation and of oversiglit of admimistration conferred upon the Congress, both by the Constitution and by the Legislative Reorganization Act of $1946,{ }^{72}$ would seem clearly to include the authority to require the disclosure of imformation needed to exercise these powers; hence, disclosure to a congressional committee would likewise be "authorized by law" and not prohibited by title 18, section 1905 . And this was, in fact, the view taken by the Attorney General in an opimion to the President of June 15,1955 , as to the authority of the Federal Communications Commission

70 Emphasis added.

7141 Ops. ATr'y Gen. No. 26 (1953).

7260 Stat. 812 (codified in scattered sections of U.S.C.). 
to make available certain information to the Senate Committee on Interstate and Foreign Commerce. ${ }^{73}$

\section{Congressional and Executtue Practice}

Both Attorney Generals Brownell and Rogers rely strongly upon past executive refusals to comply with congressional investigative demandsrefusals usually justified, upon supposed legal grounds, by opinions of the Attorney General. A repeated executive practice and the opinions of the highest legal officers are, of course, entitled to respect and may well tilt the balance in unclear cases. But they can hardly be considered as conclusive or foreclose independent inquiry into the law, in the absence of authoritative judicial decisions on the subject.

Neither opinions of the Attorney General nor the practice of the executive can justify unwarranted distortions of the Constitution. An opinion of the Attorney General is not, like the decision of a court, an authoritative formulation of the law. It is entitled only to the respect that its inherent merit wins for it; otherwise, its status-no matter what the governmental dignity of the officer rendering it-is only that of advice given by a lawyer to his client. As the late Justice Jackson, himself a former Attorney General, aptly characterized it, the view of the Attolney General is "partisan advocacy," which cannot bind later judicial judgment. ${ }^{74}$

Nor can more be said for the legal authority of executive practice in this field. That there have been numerous refusals by the executive to supply information to the Congress does not, of itself, prove that such refusals were legally justified. It should not be forgotten that, in political, as in natural, science, nature abhors a vacuum. If the Congress is derelict in asserting any of its prerogatives, executive pretensions will rush in to fill up the power vacuum. But the fact that such protensions may never have been repulsed does not demonstrate that they are valid in the first place. Nor does a governmental practice conceived in error become elevated to the plane of legality merely because the error has been long persisted in.

Even more important is the fact that the opinions of the Attorney General and others who rely upon executive refusals to supply information ignore the fact that there have been literally innumerable cases in which congressional investigative demands were complied with. Throughout our history, indeed, there have been legislative probes into the operation of the executive, whose success has been wholly dependent upon the furnishing of the necessary information by the relevant departments and agencies.

73 See Replites from Federat Agencies to Questionname Submitted by the Spectat Subcomamttee on Governarent Information of the House Committee on Government Operations, 84th Cong., 1st Sess., 165 (1955).

74 Concurring, in Youngstown Sheet \& Tube Co. v. Sawyer, 343 U.S. 579, 649, n.17 (1952). 
In actuality, instances of congressional investigations into the workings of the executive are legion. In fact, the very first congressional inquirythat into the disaster that befell General St. Clair and his army--was of this very type. Following the St. Clair investigation, both the House and Senate engaged in a great many inquiries into the workings of Government agencies. Thus, to take some illustrative examples from our early history, the House conducted general investigations into the operations of the Treasury Department (1800 and 1824), the territorial government of Mississippi (1800), the War Department (1809 and 1832), the conduct of Gen. James Willkinson (1810), Government "clerks" generally (1818), the post office (1820 and 1822), the Bank of the United States (1832 and 1834), the New York Customs House (1839), the conduct of Capt. J. D. Elliott command$\mathrm{mg}$ a naval squadron in the Mediterranean (1839), the Commissioner of Indian Affairs (1849), the Secretary of the Interior (1850), and the Smithsonian Institution (1855). During the same period the Senate was, among other things, investigating Gen. Andrew Jackson's conduct of the Seminole Wars in Florida (1818), the Internal Revenue Bureau (1828), the Post Office (1830), and John Brown's raid at Harper's Ferry (1859). Soon after the outbreak of the Civil War, the Union disasters at Bull Run and Ball's Bluff led the House and Senate to establish a joint committee "to inquire into the conduct of the present war."75

Of particular relevance is the resolution of the House of January 16, 1818 , authorizing a searching inquiry into the conduct of clerks and officials in the executive departments. Under it, a committee was appointed "to inquire whether any or what clerks or other officers in either of the Departnients, or in any office at the seat of the General Government, have conducted improperly in their official duties ..."76

Congressional inquiries into the executive were, in truth, so common in our early history that a historian of the period could conclude: "Committees instituted inquiries, ran the eye up and down accounts, pointed out little items, snuffed about dark corners, peeped behind curtains and under beds, and exploited every cupboard of the Executive household ..."77

It is to be noted that the powers of the Congress to inquire into the operations of the Government were not opposed by the agencies concerned. On the contrary, in some cases, the investigations were actually invited by the officers whose conduct was involved. Thus, on November 24, 1800, the Speaker laid before the House a letter fron Mr. Wolcott, the Secretary of the Treasury, stating that the President had accepted his resignation and,

75 See Taytor, Grand Inquest 33-34 (1955).

763 Hinds' Precedents of the House of Representatives 85-86 (1907). See also the House resolution of December 13, 1836, which authorized an even broader investigation of the executive. 4 Cong. Grobe, 24th Cong., 2d Sess. 2 (1836).

773 Schoulfr, History of THE UNITED STATES 258 (rev. ed. 1885). 
because of criticisms of his administration, freely submitting his entire conduct to "any investigation which the House of Representatives may be pleased to institute." The comment of one Congressman as to this letter is especially pertinent: "If it be understood that, on the retirement of every Secretary of the Treasury from office, an inquiry is to be inade into his official conduct, it will operate as a general stimulus to the faithful discharge of duty."78

The precedent set by Wolcott in 1800 was followed by John C. Calhoun in 1826. On December 29 of that year, the Speaker laid before the House a letter from Calhoun requesting an investigation of charges made against his prior admimistration of the War Department. "An inperious sense of duty," Calhoun wrote, "and a sacred regard to the honor of the situation which I occupy compel me to approach your body, in its high character of the grand inquest of the nation. ... In claiming the investigation of the House I am sensible that under our free and happy institutions the conduct of public servants is a fair subject of the closest scrutiny ..."70

The Congress itself has taken a strong view on the propriety of investigations by it into the workings of the executive. Thus, the House very early overruled the objection that its inquiry into the conduct of clerks in the executive departments would be an infringement on the executive power. The objection arose out of the resolution of January 16, 1818 (already referred to), authorizing a committee to inquire into the conduct of "clerks or other officers" of the departments. "Objection being made that the House would, by adopting this resolution, assume power over the Departments that belonged to the Executive and would thus impair Executive responsibility, it was answered that the House was in the relation of a grand jury to the nation, and that it was the duty of the Fouse to examine into the conduct of public officers."

Similarly, in 1874, the House, in reply to a claim that an inquiry exceeded the power of the House, "asserted its authority as grand inquest of the nation to investigate, with the attendant right of punishment for contempt ..." ${ }^{81}$ And, in 1837, the House voted to commit for conteinpt a witness for refusing to obey the subpena of a committee empowered

to inquire into the condition of the various Executive Departments, the ability and integrity with which they have been conclucted, into the manner in which the public business has been discharged in all of then, and into all causes of complaint from any quarter at the manner in which said departinents, or their bureaus or officers, or any of their officers or agents of every description whatever, directly or indirectly connected with them in any

78 Annals of Cong. 786-88 (1800) [1789-1800].

793 HINDS' PRECEDENTS OF THE HOUSE OF REPRESENTATIVES 97 (1907).

$80 \mathrm{Id}$. at $85-86$.

81 Id. at 37 . 
manner, officially or unofficially, in duties pertaining to the public interest, have fulfilled or failed to accomplish the objects of their creation, or have violated their duties, or have injured and impaired the public service and interest ..."182

An extremely suggestive precedent is to be found in the Senate in 1886. In January 1886, the Senate passed the following resolution: "Resolved, That the Attorney General of the United States be, and he hereby is, directed to transmit to the Senate copies of all documents and papers that have been filed in the Department of Justice since the 1st day of January, A.D. 1885 , in relation to the management and conduct of the office of district attorney of the United States of the southern district of Alabama."s3

Upon the Attorney General's refusal to transmit the papers requested, the Senate Committee on the Judiciary submitted a report which strongly affirmed the right of Congress to receive the information requested:

It is believed that there is no instance of civilized governments having bodies representative of the people or of states in which the right and the power of those representative bodies to obtain in one form or another complete information as to every paper and transaction in any of the executive departments thereof does not exist, even though such papers might relate to what is ordinarily an executive function....

Why should the facts as they may appear from the papers on file be suppressed? Is it because that, being brought to light, it would appear that mahice and misrepresentation and perjury are somewhat abundant ... ? ${ }^{84}$

Following this report, the Senate strongly censured the Attorney General.

In the debate in the Senate, Seantor Edmunds, the then chairman of the Judiciary Committee, referred to the "universal power of knowledge and information of the two Houses of Congress in respect to every operation of the Government of the Umited States and every one of its officers, foreign and domestic." According to hin, both Houses of the Congress had a "right to know everything that is in the Executive Departments of the Government." 85

The learned Senator stated that this was the first instance in some 40 years in which either House had failed "on its call to get information that it has asked for from the public Departments of the Government." The committees of either House, said he, "have always obtained from the departments on their mere request everything that either House or its committees thought necessary for the proper discharge of their duties."

The willingness displayed by the executive branch in furnishing information to the various committees and to the respective Houses of Congress,

82 Id. at 2-3.

837 Senate Misc. Docs., 52d Cong., 2d Sess. 236 (1893).

84 Id. at $237-43$.

8517 Cong. Rec. 2215 (1886).

86 Ibid. 
in the period ... [referred to by the Senator], is best observed by a perusal of some of the examples cited by Seantor Edmunds in his argument on the opening day of this debate im the Senate on March 8, 1886. The wide range of subjects involved in the submissions of information through the years is also worthy of notice.

In executive session on March 3, 1806, the President was requested to report all documents and papers relative to the interference of the American Minister at Paris in the case of the ship New Jersey. The President furnished this information, although there was no question then pending in the Senate regarding either the ship New Jersey or the American Minister at Paris.

The President was requested by the Senate on June 2,1813, to inform the Senate, and the Senate was so informed by the Chief Executive, whether any communications had been received from one Russell, an agent of the United States, admitting or denying the declaration of the Duke of Bassano, as to the repeal of the Berlin and Milan decrees. With respect to this, Senator Edmunds said:

"It has been stated that an agent of the United States had got [sic] that information and had given it away in an improper manner; but the detail of it is quite unnecessary now to go into; ... . in order, I repeat, to keep itself acquainted with the state of the Union and the executive affairs of this Government and the conduct of all its agents, [Congress called] for this information, and got it as a matter of course. It was not exercising a jurisdiction to confirm or reject Russell for anything, or to ratify or reject a treaty. It was getting information in a general way for its general purposes in the exercise of its general duty."

The Senate Committee on the Judiciary was instructed on March 13, 1822 , to procure from the Secretary of State a letter written by a Mr. Jennings of the State of Indiana, recommending one Dewey for appointinent as United States attorney for Indiana. The Senator indicated that the resolution instructing the committee to obtain this paper implied that the power to secure the same extended to a private paper, so far as such a paper ... [could] be a private paper, and described the document in question as being a letter that the Senate had reason to believe was in the files of ... [the] Department of State. The paper was turned over to the committee without objection.

The Secretary of War was directed by the Senate on October 30, 1828, to furnish copies of the reports of the Inspector General of the Army of the United States, confidential as well as others, including the details of all statements and instructions. This order was adopted in executive session and was compled with by the Secretary of War as a matter of course.

The Senator similarly cited numerous other occasions on which the Executive had without argument surrendered information to Congress. But of all the cases amassed by ... [Senator Edmunds] in this discussion, his last probably had the most telling effect. In March and April of 1879, the Senate Judiciary Committee ... had sought and received from the Attorney General the same type of information which Cleveland and his Attorney General, Mr. Garland, were refusing to submit to the Senate Judiciary Committee in 1886. The information requested in 1879 concerned nominations 
for certain vacancies and also dealt with the propriety of the removal of one Michael Schaeffer, Chief Justice of the Supreme Court of the Territory of Utah, and the appointment of David Corbin to that office. ${ }^{87}$

It is true, as already stated, that there have also been executive refusals to furnish papers to the Congress. These have, all the same, been relatively few by comparison with the whole mass of instances in which congressional demands for infornation have been conphed with. If executive and legislative practice is to be considered in a legal analysis of the subject, the grants as well as the refusals of information should be considered if a true picture of the prior practice is to be obtained. The readiness displayed by executive and administrative agencies in innumerable cases in furnishing information to committees of both Houses is at least as strong as a precedent as the comparatively rare instances of refusals.

This point was well made by Congressman Meader of Michigan during the questioning of the present writer in a 1956 hearing:

Mr. Meader. Let me ask you if there is not just as respectable a history of precedents where the executive branch of the Government has given information to Congress on request of congressional committees?

Professor Schwartz. Yes.

Mr. Meader. Would that not argue just as strongly that because the executive time after time had obeyed the order of the Congress and had furnished information upon request, that therefore the right existed in the Congress to have that information and it had the power to have that information and it had consistently been recognized by the executive branch?

Professor Schwartz. Yes, except, of course, the executive answer is that the accessions to congressional demands are matters of grace. We have the power to refuse but we are going to be good about it and not do it.

Mr. Meader. Could not the argument be made, on the other hand, that the Congress in not pressing and exercising its power was using its discretion to acquiesce and as a matter of grace, in the specific instance did not press the point?

Professor Schwartz. Yes, I think certainly. ${ }^{88}$

\section{Scope of Congressional Power to Investigate Executive}

The bulk of the cases cited by those who assert a claim of absolute executive privilege have to do with attempts by private litigants to compel the disclosure of executive documents in suits in the courts. Even those cases, as has already been shown, do not sustain the extreme claims of privilege made, for example, by Attorney General Brownell in his memo-

87 Collins, The Power of Congressional Committees of Investigation to Obtain Information fron the Executive Branch: The Argument for the Legislative Branch, 39 Geo. L.J. 563, 571-72 (1951).

88 Hearings on Availability of Information from Federal Departments and Agencies, Before a Subcommittee of the House Committee on Governmental Operations, 84th Cong., 2d Sess., pt. 3, 501 (1956). 
randum in support of the President's letter of May 17, 1954, to the Secretary of Defense.

Even more important perhaps is the fact that such private-law cases are not directly relevant to the power of the Congress to compel disclosure of information. It is true that the administration of justice between private litigants is important and is not to be overridden except in the face of compelling necessity. In such cases, however, governmental necessities may outweigh the needs of the private parties. The same does not apply to a congressional investigation. Here it is not merely the rights of individual litigants that are at stake. The elected representatives of the people are asserting their need for information on behalf of the nation itself, so that their legislative power may be guided in its exercise by knowledge of what needs to be known. In such a case, can the executive pull down in the legislature's face the curtain of official secrecy? ${ }^{80}$

In the case of a congressional investigation, the cases bearing solely on the power of the courts to compel disclosure are not directly relevant. Whatever limits may be imposed on the courts in the conduct of litigation can have little bearing on the scope of congressional investigatory authority.

This has been expressly recognized by the Supreme Court. In United States v. Morton Salt Co., ${ }^{80}$ the Court distinguished administrative investigatory power from that of a tribunal endowed only with judicial power. Said Justice Jackson there,

Because judicial power is reluctant if not unable to summon evidence until it is shown to be relevant to issues in litigation, it does not follow that an administrative agency charged with seeing that the laws are enforced may not have and exercise powers of original inquiry. It has a power of inquisition, if one chooses to call it that, which is not derived from the judicial function. It is more analogous to the Grand Jury, which does not depend on a case or controversy for power to get evidence but can investigate merely on suspicion that the law is bemg violated, or even just because it wants assurance that it is not.91

Can it reasonably be contended that such broad powers of investigation are possessed by an agency which is only a delegate of the Congress and not by the Congress itself from whence the delegate derived its authority?

On the contrary, in Oklahoma Press Publishing Co. v. Walling, ${ }^{02}$ the high bench expressly stated that the congressional investigatory power is at least as extensive as that of an administrative agency. It involved a subpena of the Administrator of the Wage and Hour Division directing the production by a company of certain of its records, including records which

88 Cf. Tayzor, Grand Inquest 98 (1955).

80338 U.S. 632 (1950).

91 Id. at 642 .

92327 U.S. 186 (1946). 
would indicate whether or not the coinpany had a sufficient relationship to interstate commerce to bring it within the jurisdiction and coverage of the Fair Labor Standards Act. The company, in opposing the subpena, contended inter alia that at least "probable cause" for jurisdiction over it must be shown before it could be lawfully required by subpena to produce its records. The Court rejected this contention of the appellant company, holding that "probable cause" for jurisdiction did not have to be shown in order to validate the subpena- - that the Administrator had jurisdiction to compel the production of documents in order that he might determine whether the facts showed that a case existed within the jurisdiction of the Fair Labor Standards Act.

The Court, then, proceeded to liken the powers of the Administrator, which were granted to him by the Congress, to the inquisitorial power of a grand jury. In a footnote to its opinion, the Court stated that the investigating power of the Congress, itself, was of the same character. It seeins reasonable to conclude that, if the Congress can vest in the Administrator of the Wage and Hour Division such a power of investigation, limited only by the Fair Labor Standards Act, Congress itself may do at least the same in conducting its own investigations in aid of its own powers. ${ }^{93}$

Judicial power depends upon a "case or controversy" for authority to get evidence. And in the field of administrative law a reviewing court's function is severely bmited. The judge looks only to see if a challenged administrative act is reasonably supported in fact and law. He is limited to the decision under review and the record on which it was made; he clearly cannot probe behind that record to scrutinize the decisional processes of the administrator.

But these limitations cannot apply to frustrate a congressional probe into the workings of governmental agencies. The legislature in such a case is not limited to reviewing the legality of particular challenged administrative decisions with a view to reversing those found illegal. On the contrary, it is seeking to obtain infornation on the actual operation of the Government-information whicl may ultimately serve as a basis for direct legislative action. To determine how the agencies really function, it inust be able to probe behind the ostensible formal record, in order to determine what factors actually entered into criticized agency acts. Unlike a court, it is not limited to reviewing the legality of specific decisions brought before it in particular "cases or controversies." It can investigate administrative operations merely on suspicion that the law is being violated or merely because it wants assurance that it is not. And the end result of the legislative

93 See Collins, The Power of Congressional Committees of Investigation to Obtain Information from the Executive Branch: The Argument for the Legislative Branch, 39 GEo. L.J. 563,597 (1951). 
inquiry is not the affirmance or reversal of the agency concerned, but recommendations for specific legislative action, where such are deemed necessary.

The attempt to place congressional investigatory authority within the Procrustean limitations of judicial power is thus wholly unwarranted. Congressional powers of inquiry are not limited to those possessed by a court in a specific "case" or "controversy." They are, as the Supreme Court has itself recognized, ${ }^{04}$ at least as broad as those of a grand jury. ${ }^{05}$

The investigatory powers of a grand jury are, of course, extremely broad. As the Supreme Court has said, in language at least as applicable to a legislative body, "It is a grand inquest, a body with powers of investigation and inquisition, the scope of whose inquiries is not to be limited narrowly by questions of propriety or forecasts of the probable result of the investigation, or by doubts whether any particular individual will be found properly subject to an accusation of crime." ${ }^{208}$

The conception of the Congress, hike the grand jury, as a "grand inquest" is one which has its antecedents in centuries of Anglo-American history. The roots of the congressional investigatory power lie deep in the British Parliament. Under the leading modern Britisl case, "the Commons are, in the words of Lord Coke, the general inquisitors of the realm ... they may inquire into every thing which it concerns the public weal for them to know."

It may be claimed that Lord Coke's famous assertion referred to in this quote is too extreme when applied to our Congress. It has been argued that the British precedent is not apposite because the Parliament was, unlike the Congress, originally a judicial body. ${ }^{08}$ More recent scholarship, however, vigorously denies that Parliament ever really was a court, in our modern sense of the term..$^{99}$ Then, too, the English cases on legislative investigatory authority all arose long after Parhament clearly ceased to be a court. Thus, even if Parliament had once been a judicial body, that should hardly affect the value for us of precedents that took place long after it had ceased to be such.

In $M c$ Grain v. Daugherty, ${ }^{100}$ the Supreme Court clearly indicated that the congressional investigatory power was derived from that of the Par-

${ }^{94}$ Oklahoma Press Publishing Co. v. Walling, 327 U.S. 186 (1946).

05 For a similar holding, see also Umited States v. Moran, 194 F.2d 623 (2d Cir. 1952), cert. denied, 343 U.S. 965 (1952).

96 Blair v. United States, 250 U.S. 273, 282 (1919). See, similarly, United States v. Johnson, 319 U.S. 503, 510 (1943); United States v. Neff, 212 F.2d 297 (3d Cir. 1954); Homan Mfg. Co. v. Russo, 233 F.2d 547 (7th Cir. 1956).

${ }^{\circ 7}$ Howard v. Gosset, 10 Q.B. 359, 379-80, 116 Eng. Rep. 139, 147 (1845).

${ }^{88}$ See Kilbourn v. Thompson, 103 U.S. 168, 189 (1880).

${ }^{99}$ See Potts, Power of Legislative Bodies to Punish for Contempt, 74 U. PA. L. REv. 691, 692-99 (1926).

100273 U.S. 135 (1927), note 25 supra. 
liament. Said the Court there, "In actual legislative practice power to secure needed information by such means has long been treated as an attribute of the power to legislate. It was so regarded in the British Parliament and in the Colonial legislatures before the American Revolution; and a like view has prevailed and been carried into effect in both houses of Congress and in most of the state legislatures."101

It is relevant to note that a member of the very first Supreme Court spoke of the investigatory power of the House of Representatives in language strikingly similar to that of Lord Coke. Lecturing in Pliiladelphia in 1791, Mr. Justice Wilson affirmed, "Tlie house of representatives ... form the grand inquest of the state. They will diligently inquire into grievances, arising both from men and things." 102

Interestingly enougl, when the House called upon the Father of his Country himself to produce the records relating to the expedition of General St. Clair, President Waslington's Cabinet unanimously determined: "First, that the House was an inquest and therefore might institute inquiries. Second, that they might call for papers generally...."103

Can it reasonably be claimed that the "grand inquest" of the nation does not liave the power to conduct the broadest possible investigation into the workings of the executive? On the contrary, the Congress may well say, as did the Massachusetts House of Representatives in 1722, that it is "not only their Privilege but Duty to demand of any Officer in the pay and service of this Government an account of his Management while in the Public Imploy."104

Nor, it should be emphasized, is the power of the Congress to demand information from the executive affected by the limitations on congressional investigatory authority laid down by the Suprene Court in its recent decision in Watkins v. United States. ${ }^{105}$ The Watkins case concerned an investigation of a private individual. Its language is not relevant to demands for information made in investigations into the operation of departments and agencies. In sucli an inquiry, there is none of the danger of so-called exposure "for the sake of exposure"106 against which the Watkins opinion inveiglied. To such an investigation, the strictures of the Watkins Court can have no application.

The opinion of the Clief Justice in Watkins, indeed, contains a clear recognition of this distinction between the Watkins type of investigation

$101 \mathrm{Id}$. at 161.

1022 WORKS OF JAMES WIISON 29 (1896).

103 Quoted in TAYIOR, Grand InQUest 23 (1955).

${ }^{104}$ Quoted in Potts, Power of Legislative Bodies to Punish for Contempt, 74 U. PA. L. Rev. 691, 708 (1926).

105354 U.S. 178 (1957).

108 Id. at 200 . 
and inquiry into the executive branch. "The public," categorically declares Chief Justice Warren, "is, of course, entitled to be informed concerning the workings of its government." ${ }^{107}$ And he goes on to state expressly: "We are not concerned with the power of the Congress to inquire into and publicize corruption, maladministration or inefficiency in agencies of the Government. That was the only kind of activity described by Woodrow Wilson in Congressional Government when he wrote: 'The imforming function of Congress should be preferred even to its legislative function.' . . . From the earliest times in its history, the Congress has assiduously performed an 'informing function' of this nature." 108

Watkins clearly implies a preferred position for congressional investigation into the workings of government agencies. The Watkins limitations on the congressional power to obtain information thus do not apply to demands made of the executive itself in the course of probes into the operation of the Government. On the contrary, to executive refusals interposed to such demands, the Congress might well respond, as once did William Pitt, the Elder: "We are called the Grand Inquest of the Nation, and as such it is our duty to inquire into every Step of publick management, either Abroad or at Home, in order to see that nothing has been done amiss."100

\section{Some State Cases}

Reference has already been made to the assertion of Attorney General Brownell in his memorandum in support of the President's letter of May 17, 1954 that the courts have uniformly upheld the doctrine of absolute executive privilege vis-a-vis the Congress. ${ }^{110} \mathrm{He}$ cites no court case so holding, and, in fact, cannot do so, for there is no judicial decision in accordance with his assertion. In fact, as cases already discussed show, it may be doubted whether the courts recognize any absolute executive privilege, even as against a private citizen in ordinary private litigation.

As against the vacuum of relevant precedents in support of claims like that of Mr. Brownell's to an extreme executive privilege, there are, it should be noted, a number of court decisions expressly sustaining the legislative power to investigate government agencies and to require the production of papers and documents in connection therewith. In this connection, it is apposite to point out that the leading case on congressional investigatory power itself, McGrain $v$. Daugherty, ${ }^{111}$ arose out of an investigation of the executive departments imphicated in the Teapot Dome scandals. While the

10913 Comorons Debates 172. It is from the Pitt speech that Taylor, op. cit. supra note 16, derived the title of his work on congressional investigations. 
Court did not emphasize the fact that the investigation at issue was one into the workings of Government agencies (but, instead, delivered an opinion sustaining congressional investigatory power generally), its decision is clearly authority for broad investigation by the Congress into executive operations.

Several state decisions make exphicit the major premise implicit in McGrain v. Daugherty. One of the earliest cases on the subject is Burnham v. Morrissey. ${ }^{112}$ In that case, a special committee was appointed to investigate the state liquor agency. The commissioner in charge refused to produce certain books. He was committed for contenpt and sought habeas corpus. The writ was discharged, the court expressly declaring that the House had full authority to compel witnesses to furnish such information for "the proper performance of legislative duties." 113

A similar case is Ex parte Parker. ${ }^{114}$ There, too, the state liquor agency was under investigation and the court, in refusing to discharge a contumacious witness, declared: "The power of the General Assembly to obtain information on any subject upon which it has power to legislate, with a view to its enlightenment and guidance, is so obviously essential to the performance of legislative functions that it has always been exercised without question."115

Perhaps the leading state case until recently was People ex rel. McDonald $v$. Keeler. ${ }^{116}$ It involved a legislative investigation into the operations of the department of public works. The court upheld the legislative power to undertake such an investigation, saying, "It is a well-established principle ... that either House may institute any investigation having reference to ... any nuatter affecting the public interest upon which it may be important that it should have exact information, and in respect to which it would be competent for it to legislate. ${ }^{2117}$

The cases just discussed clearly uphold the legislative power to obtain information on the workings of the executive. Even more pertinent, perhaps, is a 1951 Massachusetts decision, which arose directly out of an executive attempt to pull down in the legislature's face the curtain of official secrecy. In 1951, the Massachusetts Development and Industrial Commission, an agency within the executive department, ordered a study made of business conditions. When this study was completed and a report made, the State Senate ordered the chairman of the commission to produce the report. He

11280 Mass. (14 Gray) 226 (1859).

113 Id. at 239.

11474 S.C. 466,55 S.E. 122 (1906).

115 Id. at 470,55 S.E. at 124 .

11699 N.Y. 463 (1885).

117 It is interesting to note that the New York court here was anticipating the famous language of Justice Van Devanter in McGrain v. Daugherty, 273 U.S. at 174-75. 
refused, asserting that "the legislature may not attempt to interfere with action taken by the executive department." He was backed up in his defiance by a formal vote of the commission directing that the report be turned over to a private advisory group. Thus, there was squarely presented to a court for the first and only time the direct question of whether the executive can refuse to turn over to the legislature an internal communication on the ground of executive privilege.

The claimed privilege was wholly rejected by the Massachusetts court, which upheld the power of the State Senate to enforce its demand for the report, by contempt proceedings if need be. According to the court, "If the legislative department were to be shut off in the manner proposed from access to the papers and records of executive and administrative departments, boards, and commissions, it could not properly perform its legislative functions." 118

It needs little iteration to note the extreme relevancy of this Massachusetts decision. Here we have the only case in which the pretensions of the executive to a power to withhold documents from the legislature on the ground of privilege were squarely presented to a court. And the court expressly repudiated the gratuitous assumption of such a power in the executive to frustrate a legislative inquiry.

At issue in the Massachusetts case was the claimed privilege of the executive with regard to communications within an executive agency. It should be noted that these are exactly the communications asserted to be wholly privileged in the President's letter of May 17, 1954, to the Secretary of Defense. ${ }^{119}$.Yet, in the one case where the claimed privilege has had to run the judicial gantlet, it was weighed in the balance and found wanting by the highest court of Massachusetts.

\section{INDEPENDENT AGENCIES}

In his already-referred to statement to the Senate subcommittee, Attorney General Rogers did not limit his claim of executive privilege to agencies in the executive branch, strictly speaking. Instead, he asserted a power to withhold information from the Congress even in the supposedly independent regulatory commissions, of the type of the Interstate Commerce Commission. ${ }^{120}$ In this portion of his statement, Mr. Rogers was really giving the seal-of-approval of his office to the claim made by the Civil Aeronautics Board, mentioned at the beginning of this article, ${ }^{121}$ to determine which of

118 Opinion of the Justices to the Senate, 328 Mass. 655,661 (1951).

119 See text at note 14 supra.

120 Rogers, Constitutional Law: The Papers of the Executive Branch, 44 A.B.A.J. 941, 1013-14 (1958).

121 See notes 4-5 stitra and accompanying text. 
its files and records should be made available to the House Legislative Oversight Subcommittee.

The claims of both Mr. Rogers and the CAB in this respect are contrary to the whole theory of the independent regulatory commission. It is one thing-unsound though even it may be-to assert a theory of privilege for the President and the heads of the executive departments and altogether another to claim such a privilege for an independent agency like the CAB. Under a doctrine of absolute privilege in the President, it may be that we would in effect, come close to adopting the view of the Presidency attributed to William H. Seward: "We elect a king for 4 years, and give him absolute power."122 But not even the most extreme advocate of executive privilege, one inay assume, would advocate a rewording of the historical maxim to read: "The Civil Aeronautics Board can do no wrong."

As already pointed out, the claims of the proponents of executive privilege are based upon the doctrine of the separation of powers. Under it, the Congress is the legislative department of the Government; the President is the executive department. ${ }^{123}$ It is difficult to see how this separation-ofpowers reasoning can have any validity as far as an independent agency like the $C A B$ is concerned. Such a body is clearly not a part of the executive branch, subject to the hierarchical control of the President. If the approach of Attorney General Rogers is applied to it, the $\mathrm{CAB}$ would be responsible neither to the Congress nor the President. Then, in truth, would we have established in our system what has been well termed "a headless 'fourth branch of the Government,' a haphazard deposit of irresponsible agencies and uncoordinated powers."

That an agency like the Civil Aeronautics Board cannot be treated merely as an ordinary executive agency has been clear ever since the celebrated decision of the Supreme Court in Humphrey's Executor v. United States. ${ }^{125}$ That case arose out of the removal from office by President Roosevelt of a menber of the Federal Trade Commission, who had been appointed by his predecessor in office in 1931 for a term of 7 years, on the ground "that the aims and purposes of the Administration with respect to the work of the Commission can be carried out most effectively with personnel of my own selection."126 The applicable statute provided that members of the Commission were to hold office for terms of 7 years and that "any Commissioner may be removed by the President for inefficiency, neglect of duty, or malfeasance in office."

122 Quoted in Schwartz, The Supreare Court 98 (1957).

123 See Mississippi v. Johnson, 71 U.S. (4 Wall.) 475, 500 (1866).

124 Report of the President's Comamttee on Administrative Managemant 39 (1937).

125295 U.S. 602 (1935).

128 Id. at 618.

12738 Stat. 717 (1914), 15 U.S.C. $\$ 41$ (1952). 
The Court in the Humphrey case held that the President did not possess the wide removal power over members of the Commission which he had over officers appointed by him in the ordinary executive departments. Pointing to the quasi-judicial functions of the Commission Mr. Justice Sutherland asserted that freedom from presidential control was vital to their successful execution. "The authority of Congress," reads his opinion, "in creating quasi-legislative or quasi-judicial agencies, to require them to act in discharge of their duties independently of executive control cannot well be doubted; and that authority includes, as an appropriate incident, power to fix the period during which they shall contimue in office, and to forbid their removal except for cause in the meantime. For it is quite evident that one who holds his office only during the pleasure of another, cannot be depended upon to maintain an attitude of independence against the latter's will."128

To get a true picture of the status of an independent agency like the Federal Trade Commission or the Civil Aeronautics Board by comparison with a purely executive agency, one must summarize the factors that have led the Congress to create such agencies outside the executive branch:

(1) As a practical matter, there is no doubt that a primary factor has been the example of the Interstate Commerce Commission. The success and prestige (particularly in its earher years) of the first important regulatory agency have greatly influenced the Congress to set up other commissions and boards modeled upon it. This is clear from the legislative history of most of the independent agencies. The witnesses and committee reports constantly refer to the Interstate Commerce Commission as a model.

(2) Independence has been viewed as a means of securing impartiality in administration. Because of the vast powers vested in these agencies and the tremendous pressures to which they may be subject, it has been felt essential that they be insulated from partisan influence or control to the maximum extent feasible. Independence of the executive and security of tenure were intended to assure freedom from partisan control. Also intended to secure such freedom has been the requirement of bipartisanship in appointments, contaimed in the enabling statutes of these agencies.

(3) The quasi-judicial nature of these agencies' work also militates against placing them under direct executive control. Such judicial functions must, consistent with American traditions, be performed in an atmosphere of independence from the executive.

(4) The independent agency was designed to assure a body of experts competent to deal with highly complicated and technical problems. Independence from the executive has been deemed to enhance the professional qualities of the agency, enabling both the heads and the staff to secure the expertise needed for effective regulation.

128295 U.S. at 629 . The Humphrey decision has recently been reaffirmed in Wiener v. 
(5) Closely connected with the need for expertness has been the need for stability and continuity of policy. For those regulated to plan effectively, the regulatory agency must achieve a basic stability in methods and policy. With an independent body whose members are held for substantial and overlapping terms of office, continuity of policy and stability of administrative method could be built up.

(6) Because of the importance of their tasks, the Congress has sought to vest in these agencies the added prestige associated with independence from the executive. It would be easier, it was felt, to secure impartial and able men to serve on an independent body.

Because of these factors, the Congress has felt it to be undesirable for agencies like the Civil Aeronautics Board to be subject to the hierarchical power of the President. Does this mean then that they are to be subject to no direct supervision, responsible to no one but their own discretion in the administration of their enabling laws?

Congressional intent clearly points to a categorical negative in response to this question. In insulating the independent agencies from executive control, the Congress did not design them to be in an irresponsible position. On the contrary, agencies like the Civil Aeronautics Board are, unlike the executive departments, intended to be primarily agents of the Congress. Thus, Senator (later Mr. Justice) Sutherland, speaking in the debate on the Federal Trade Commission Act of 1914, referred to the proposed agency as a "legislative commission."

The Supreme Court has also adopted this position. In the already referred to Humphrey case, a unaminous Court declared: "The Federal Trade Commission is an administrative body created by Congress to carry into effect legislative policies embodied in the statute in accordance with the legislative standard therein prescribed.... Such a body cannot in any proper sense be characterized as an arm or an eye of the executive. Its duties are performed without executive leave and, in the contemplation of the statute, must be free from executive control."

It should not be forgotten that an independent agency like the FTC or $\mathrm{CAB}$ is wholly a creature of the Congress. As was well pointed out by James M. Landis, himself a former chairman and member of three of the independent agencies, "Save for the few constitutionally organized departments of government, the administrative and executive agencies exist only by the will of Congress . . . No constitutional duty demands their continuance. Congress may abolish them at its pleasure, redistribute them, consolidate or divide them."

129 Quoted in Cusharan, The Independent Regulatory Commisstons 198 (1941).

130295 U.S. at 628.

131 Landis, Constitutional Limitations on the Congressional Power of Investigation, 40 HARv. L. REv. 153, 196 (1926). 
With regard to an independent regulatory agency, the congressional role is essentially that of principal to agent. It is the primary duty of an agent continually to account to his principal, and a corollary responsibility of the principal to exercise continuing supervision over his agent. ${ }^{132} \mathrm{Can}$ an agent really claim a privilege to withhold from his principal any information or records relating to his agency? If he could, would that not make a mockery of his duty to account to his principal?

\section{Privingge and Statule-LaW}

Legal rules, unlike those in the physical sciences, do not have fixed areas of strains and stresses. Instead, legal rules are, all too often, pushed to the very breaking point permitted by expediency. This has clearly been the case with the rule of executive privilege advocated by the Attorney General in recent years.

Perhaps the inost extreme assertion of executive privilege occurred only last year when the Air Force refused to honor a request of the Comptroller General for access to a survey of management of the Air Force ballistic missile program. The General Accounting Office had previously begun a review of the administrative conduct and management of various Air Force activities under its research and development programs. Activities under the ballistic missile program were selected for initial study. In pursuance of such study, on June 13, 1958, the Comptroller General requested the Secretary of the Air Force to make available a copy of the Air Force Inspector General's report entitled "Survey of Management of the Ballistic Missiles Program." The Air Force Secretary, in reply, stated that the release of the report to persons outside the Department would have a serious adverse effect on effective administration. "The public interest," he asserted, "would best be served by not releasing the report." "133

To grasp the significance of the Air Force refusal in this case, one should understand the statutory position of the GAO. That agency was set up under the Budget and Accounting Act, 1921, to examine "all matters relating to the receipt, disburseinent, and application of public funds"134 and to consider and report on the economy, efficiency, and effectiveness of all federal agency activities. ${ }^{135}$ The GAO is the financial watchdog of the Congress; as such, its job is constantly to audit the performance of their functions by departments and agencies.

132 See Restatement (Second), Agency \$ 382 (1958).

133 See Hearings Before the Subcommittee on Availobility of Information from Federal Departments and Agencies of the House Committee on Government Operations, 85th Cong., 2d Sess., pt. 16, 3578 (1958).

13442 Stat. 25 (1921), 31 U.S.C. 853 (a) (1952).

135 Hearings Before the Subconmittee on Availability of Information from Federal Departments and Agencies of the House Committee on Government Operations, 85th Cong., 2d Sess., pt. 16, 3580 (1958) 
To enable the Comptroller General to perform his task, the 1921 Act conferred upon him the broadest authority to secure necessary information. According to the relevant section:

All departments and establishments shall furnish to the Comptroller General such information regarding the powers, duties, activities, organization, financial transactions, and methods of busmess of their respective offices as lie may from time to time require of them; and the Comptroller General, or any of his assistants or employees, when duly authorized by him, shall, for the purpose of securing such information, have access to and the right to examine any books, documents, papers, or records of any such department or establishment .... ${ }^{\mathbf{1 3 6}}$

In this case, in other words, there was an express statutory provision giving the Comptroller General access to all records of departments and agencies. Executive privilege was asserted here to contravene a federal law. As the Comptroller General himself has put it, "we believe that the action of the Secretary of the Air Force is contrary to the intent and provisions of the Budget and Accounting Act, 1921, and the Budget and Procedures Act of 1950, and that such action precludes a proper discharge of our statutory responsibilities."137

The Air Force refusal in this case is most significant for it appears to represent the first attempt to assert executive privilege in the face of the contrary provisions of a federal statute. The claim of the executive to the power to override a statute is, however, not a new one in our law. "A statute derogatory to the prerogative," declared one of the king's judges in the celebrated Ship-Money case, "doth not bind the king."138 But the whole system of Anglo-American public law since the final expulsion of the Stuarts has been based upon the repudiation of this theory. The leading modern English case is Attorney-General v. De Keyser's Royal Hotel, Ltd. ${ }^{139}$ where it was held that the enactment of statutory provisions covering the same ground as the prerogative power must be deemed pro tanto to suspend the prerogative. "The Legislature," said Lord Sumner there, "by appropriate enactment, can deal with such a subject-matter as that now in question in such a way as to abate such portions of the prerogative as apply to it."140

In this country, too, the law has been the same-from the early case of Little v. Barreme $e^{141}$ to the recent Steel Seizure ${ }^{142}$ case. Any power that the

13642 Stat. 26 (1921), 31 U.S.C. \$ 54 (1952). (Emphasis added.)

137 Hearings Before the Subcommittee on Availability of Information from Federal Departments and Agencies of the House Committee on Government Operations, 85th Cong., 2d Sess., pt. 16, 3581 (1958).

138 Rex v. Hampden, 3 How. St. Tr. 826, 1125 (1637).

139 [1920] A.C. 508.

140 Id. at 561 .

1416 U.S. (2 Cranch) 99 (1804).

143 Youngstown Sheet \& Tube Co. v. Sawyer, 343 U.S. 579 (1952). 
executive might otherwise have must give way before statute-law. Nor is the result with us affected by the constitutional authority of the President with regard to the faithful execution of the laws. This has been clear ever since Kendall v. United States. ${ }^{143}$ In that case, it was claimed that an executive officer was subject solely to the direction of the President with respect to his duty to execute a statute; this power of the President was said to grow out of the faithful execution clause. According to the Court, however, "This is a doctrine that cannot receive the sanction of this court. It would be vesting in the president a dispensing power, which has no countenance for its support, in any part of the constitution; and is asserting a priciple, which, if carried out in its results, to all cases falling within it, would be clothing the president with a power entirely to control the legislation of congress, and paralyze the administration of justice."144

The Air Force refusal to make the Inspector General's report available to the GAO is inconsistent with the basic notion of the supremacy of statute-law in our polity. ${ }^{145}$ It shows how a concept such as that of executive privilege tends to be pushed to its extreme unless it is checked by appropriate legal means.

But it also indicates that it is a fiction to speak of the President personally with regard to assertions of privilege. This is true despite the fact that-even if we assume arguendo that there is a valid executive privilege in some instances-such privilege exists only because of the constitutional position of the President himself. Despite this, in the case under discussion there is no doubt that the extreme assertion of privilege in the face of a statute was made without the shightest awareness by the President of what was being done.

We know that this is true because the President candidly admitted his ignorance of the matter at his November 5,1958 , press conference. ${ }^{146}$ It is not unreasonable to assume that the President has been equally unaware of what was done in other cases where executive privilege has been claimed. It thus turns out that the privilege of the President is asserted in practice without the least knowledge on his part of what is being done. One may wonder, indeed, whether the same is not true of department heads who

14337 U.S. (12 Pet.) 364 (1838).

$144 \mathrm{Id}$. at 611 .

145 It is also inconsistent with a 1925 opinion of the Attorney General, which, relying on $\S 313$ of the Budget \& Accounting Act of 1921, upheld the right of the Comptroller General to have access to all department and agency records, declaring: "What papers or data he should have to make such audit would seem to be a matter solely for his determination." 34 OPs. ATr'y GeN. 446, 447 (1925).

146 See Hearings Before the Subcommittee on Availability of Information from Federal Departments and Agencies of the House Committee on Government Operations, 85th Cong., 2d Sess., pt. 16, 3706 (1958). 
purportedly make the decisions in these cases. It is surely not too much to ask that decisions to withhold information from the Congress or a legislative agent like the Comptroller General be made at the very highest level of the executive hierarchy. Otherwise, we have the ludicrous result recently referred to by a Congressman-i.e., that "the departments trust their stenographers more than they trust us. That is, they refuse to give us information that folks in the office might have."147

\section{SOME SUGgestrons}

If the prior portions of this article have demonstrated anything, it is that the extreme claims of complete executive discretion to withhold information from the Congress have no legal justification. They are supported by neither statutes nor judicial precedents. They rest, therefore, solely upon the inherent authority of the executive. But the vague claim of executive prerogative, however valid it may be as a matter of internal administration, must surely give way to the clear constitutional power of the Congress to seek information. Otherwise, the admitted congressional powers of legislation and oversight of admimistration would be at the mercy of the executive when the information necessary to intelligent exercise of those powers happened to be in the possession of a department or agency.

The Attorney General and other executive officials have consistently maintained that the executive has complete discretion to withhold any information whatsoever whenever, in the opinion of the executive, the public good so requires. This extreme claim must be rejected. This does not, however, mean that the Congress must move to the opposite extreme and compel the disclosure of all executive infornation. On the contrary, whether disclosure should be compelled should depend on the nature of the information involved. In this connection, there is a fundamental distinction between information involving what are usually termed "state secrets" and other official information. According to rule 33 of the Rules of Evidence approved in 1953 by the National Conference of Commissioners on Uniform State Laws, "secret of state' means information not open or theretofore officially disclosed to the public involving the public security or concerning the military or naval organization or plans of the Umited States, or a State or Territory, or concerning international relations." "On the other hand, "official information' means [according to rule 34 of the same Rules of Evidence] information not open or theretofore officially disclosed to the public relating to internal affairs ... of the United States acquired by a public official of .... the United States in the course of his duty, or transmitted from one such official to another in the course of duty." 148 
Where other than "state secrets" are involved, there is no valid reason for executive information to be withheld from the Congress. Disclosure to the Congress of official information other than "state secrets" can have no adverse effect upon public security. What is involved in such information is not military, naval, or diplomatic secrets, but other governmental communications which, for one reason or another, the executive does not desire to see the light of day on Capitol Hill. Whatever the reasons for their nondisclosure are, they relate to what is conceived to be the proper internal functioning of government and hardly to the public safety. If the information is relevant to a congressional inquiry, why should the executive desire to keep it in obscurity be permitted to defeat the congressional need for information? If the public safety or national defense will not be affected, why slould departmental convenience weigh inore heavily than the proper performance of the legislative function?

A different situation exists when a "state secret" is involved. When the information in question involves the public security or concerns military, naval, or diplomatic matters, few will deny that they should be privileged from disclosure. Thus, plans of military organization, naval blueprints, FBI files, and the like must be placed in a special confidential position. But this does not necessarily mean that, even as to such information, one inust agree with the Attorney General that the executive assertion of privilege must be conclusive.

The difficulty with the Attorney General's view is that it assumes that the executive answer to the question of when public interest must bar the disclosure of information will necessarily coincide with the true interest of the public in all cases. One wonders, however, whether it is realistic to expect the executive always to weigh wisely and impartially the total public interest as against its own convenience. One must consider the matter in the framework of administrative realities. The diffusion of power in government departments and agencies often lodges actual responsibility in the fourth or fifth tier of the administrative lierarchy. A subordinate immediately concerned with a case may not bring to it the complete objectivity of a Lord High Chancellor. To make the liead of the department the ultimate arbiter of disclosure is, under these circumstances, no real guaranty that the determination will be based upon sound principles of public interest. The department head will mevitably take cognizance of the public interest as it is seen froin his own departmental angle, including its administrative convenience. ${ }^{149}$ Under the normal administrative routine the question will come to him with recommendations from cautious subordinates against disclosure and in the press of business the chief is likely to approve the rec-

149 See Simon, Evidence Excluded by Considerations of State Interest, [1955] Cams. I.J. 62,75 . 
ommendation without much independent consideration. ${ }^{150}$ To ensure that departmental convenience is not equated to public interest, there must be independent scrutiny of the claim of privilege, even where a "state secret" is involved.

A most useful analogy is furnished here by United States $v$, Reynolds, ${ }^{151}$ the leading case on the executive withholding of information from the courts. It arose out of the crash of a military aircraft on a flight to test secret electronic equipment, in which certain civilian observers aboard were killed. Their widows sued the United States under the Federal Tort Claims Act. The plaintiffs moved for discovery of the Air Force's official accident investigation report, but the Secretary of the Air Force filed a claim of privilege objecting to production of the document. The Supreme Court appears clearly to have adopted the view that the determination of privilege, even where "state secrets" are involved, is a judicial function. At the same time, where such secrets are present, the court should, if at all possible, not force any disclosure even to the trial judge: "The court itself must determine whether the circumstances are appropriate for the claim of privilege, and yet do so without forcing a disclosure of the very thing the privilege is designed to protect." 162

This necessitates, says Mr. Chief Justice Vinson for the Court, what he terms a "formula of compromise."

Judicial control over the evidence in a case cannot be abdicated to the caprice of executive officers. Yet we will not go so far as to say that the court may automatically require a complete disclosure to the judge before the claim of privilege will be accepted in any case. It may be possible to satisfy the court, from all the circumstances of the case, that there is a reasonable danger that compulsion of the evidence will expose military matters which, in the interest of national security, should not be divulged. When this is the case, the occasion for the privilege is appropriate, and the court should not jeopardize the security which the privilege is meant to protect by insisting upon an examination of the evidence. ${ }^{153}$

In the case under discussion, the Court felt that, from all the circumstances of the case, there was, at the least, a reasonable basis for upholding the claim that a "state secret" was involved, without the need for personal examination of the document at issue. As Chief Justice Vinson stated, "On the record before the trial court it appeared that this accident occurred to a military plane which had gone aloft to test secret electronic equipment. Certainly there was a reasonable danger that the accident investigation

150 MCCoRAITCK, EvIDENCE 307 (1954).

161345 U.S. 1 (1953).

162 Id. at 8.

163 Id. at 9-10. 
report would contain references to the secret electronic equipment which was the primary concern of the mission." 154

Under the Supreme Court's view, it is for the judge to determine whether a privilege on the ground that a "state secret" is involved is validly claimed. According to the Reynolds case, the judge's inquiry extends only to seeing whether there is a reasonable basis for the assertion of privilege. If he can satisfy himself that there is such reasonable basis from the circumstances of the case, without examining the document at issue, then such examination should not be had. In Reynolds itself, we have seen, the Court felt that such was the case. On the other hand, if examination of the document itself is necessary before the judge can decide whether a "state secret" is really involved, he can and must make such examination. Nor, as the lower court ably stated in the Reynolds case, "is there any danger to the public interest in submitting the question of privilege to the decision of the courts. The judges of the United States are public officers whose responsibility under the Constitution is just as great as that of the heads of the executive departments. When documents are submitted to them under a claim of privilege the judges may be depended upon to protect with the greatest of care the public interest in preventing the disclosure of matters which ought to be privileged. And if, as the Government asserts is sometimes the case, a knowledge of background facts is necessary to enable one properly to pass on the claim of privilege those facts also may be presented to the judge in camera." 155

It seems to the present writer that the Reynolds case furnishes the proper rule for information involving "state secrets," not only when disclosure is sought in court, but also when disclosure is sought in the Congress. If a "state secret" is actually involved, the Congress should not compel disclosure. But, to paraphrase the Supreme Court, here, too, the congressional right to information should not be abdicated to the caprice of executive officers. The congressional organ seeking disclosure should inquire to determine whether there is a reasonable basis for the executive claim and, if that basis is found to exist, more should not be demanded. What was said in the Reynolds case about the propriety of such inquiry should apply as well to cases where it is the Congress that seeks information.

It may, of course, be objected that the Congress is not a wholly proper body to perform this kind of inquiry. It will be said that, since it has a direct interest in securing the information, it is no more impartial than the executive itself in determiming whether it should be disclosed. There is force in this criticism. The objection could be overcome if the power of inquiry were vested in an independent judicial tribunal. Because of the limitations of 
judicial power in article III of the Constitution, it is doubtful that the function in question can be conferred upon the federal courts or judges. The Congress could, however, establish by law an independent Government Information Commission. This tribunal could be composed of three members appointed during good behavior. Any case in which an executive officer refused to furmish requested information to the Congress would be referred to the Commission. It would determine, in camera if necessary, whether there is a "reasonable ground" for holding that the information requested involves a "state secret." If it determines there is such ground, disclosure would not be allowed; otherwise disclosure would be compelled, under appropriate coercive powers vested im the Commission by law. Since both the executive and the Congress will, to some degree, be interested parties in the cases before the Commission, it is suggested that its members be appointed by a wholly impartial source, under an almost ignored provision of Article II (2) of the Constitution, i.e., that under which the Congress may by law vest the appointment of officers other than those expressly named "in the Courts of Law." Such appointments could be made by the Supreme Court or the Chief Justice thereof, a method which will ensure both the prestige and impartiality of the proposed commission. ${ }^{156}$

\section{Concluston}

It should be stated frankly that the suggestion just made is not advanced by the present writer with anything like dogmatic conviction. It is put forward primarily with the hope of stimulating profitable discussion on the problem dealt with. The problem itself-that of ensuring the adequate diffusion of executive information, particularly to the legislative branchis one of the most significant confronting the country and the Congress at the present time. And the problem is one which is within the legal power of the Congress to deal with, by statute or otherwise. This writer recognizes, of course, that the power is one whicl the Congress can abuse. But, as stated by the Supreme Court, in answer to the contention that the congressional power of inquiry may be abusively and oppressively exerted, even if that be true, "it affords no ground for denying the power. The same contention might be directed against the power to legislate, and of course would be unavailing." 157

It is not enough, however, merely to establish the legal authority of Congress to require disclosure of information. As Mr. Justice Jackson stated so aptly in the celebrated Steel Seizure case, "If not good law, there was wordly wisdom in the maxim attributed to Napoleon that "The tools

156 Compare Comartssion on Organization of tHe Executrve Branch of tere Government, Task Force Report on Legal Services and Procedure 264 (1955).

157 McGrain v. Daugherty, 273 U.S. 135, 175 (1927). 
belong to the man who can use them.' We may say that power ... belongs in the hands of Congress, but only Congress itself can prevent power from slipping through its fingers." 158

In the absence of effective assertions of the congressional authority to require the disclosure of information, it is hardly surprising if departments and agencies persist in assertions of unfettered discretion in themselves in the matter. To be sure, departments and agencies have a natural desire to be wholly free of investigatory demands. But the possibilities of administrative inconvenience here are surely outweighed by the overriding public interest in having the affairs of the Government carried on free of the "paper curtain" of official secrecy.

The claim of the executive that it cannot carry on its business if its internal workers are fully subject to congressional inquiry is not a new one. A similar pretention was raised in court in one of the great state trials of 18th-century England. There, counsel for the Governor and Council of the East India Company sought not to produce the council records, because, said he, it would lead to "many inconveniences and ill consequences to exhibit the proceedings of the council in an open court of justice, especially as they may sometimes contain secrets of utmost importance to the interest and even to the safety of the state ...."

The court rejected this claim of privilege, saying: "We are not surprised that the governor general and council should be desirous to prevent their books being examined, which might tend to the consequences they mention . . . but, at the same time, it is a matter of justice, that if they contain evidence material to the parties in civil suits, they may have an opportunity of availing themselves of it."

To the dangers of abuse adverted to by counsel, the court declared that it itself would ensure that proper use was made of the records produced: "When it is necessary they should be produced, the Court will take care they are not made an improper use of."159

When any individual, from the highest to the lowest, is required to heed the call of justice in the courts-no matter how piddling the particular case -can it be claimed that any public officer is not subject to the even more important demands of the "grand inquest of the nation"? In Bentham's famous words: "Were the Prince of Wales, the Archbishop of Canterbury, and the Lord High Chancellor, to be passing by in the same coach, while a chimney-sweeper and a barrow-woman were in dispute about a halfpennyworth of apples, and the chimney-sweeper or the barrow-woman were to think proper to call upon them for their evidence, could they refuse it? No; most certainly."180

158 Concurring, in Youngstown Sheet Tube Co. v. Sawyer, 343 U.S. 579, 654 (1952).

150 Trial of Maharajah Nundocomar, 20 How. St. Tr. 923, 1057 (1775).

1804 BENTHAXX, WORKS 320 (1778). 
If this is true in a court, how much more true must it be in an inquiry by the elected representatives of the people themselves. "The public," declared Lord Hardwicke, L.C., "has a right to every man's evidence ...." 161 Shall this be true of any private-law case, and not of the evidence sought in an investigation authorized by solemn resolution of the people's representatives, in Congress assembled?

It is no overstatement to say that vigorous employment by the Congress of its imvestigatory power is essential to the preservation of our representive democracy. Particularly is this true of investigations of the working of government agencies. As was stated by the late Senator Norris, "Whenever you take away from the legislative body of any country in the world the power of investigation, the power to look into the executive department and every other department of the government, you have taken a full step that will eventually lead into absolute monarchy and destroy any government such as ours."

That the learned Senator's statement was not mere exaggerated verbiage is shown by the situation in France, where the Parliament has not successfully asserted an investigatory power comparable to that associated with Anglo-American legislatures. Committees of the French Parliament have, as a practical matter, been barred from obtaining testimony and papers which were not given voluntarily. " 'We knew perfectly well,' said the president of a French parliamentary investigating committee in 1878, 'that we cannot, that the law would not permit us to, compel citizens to appear before us.' "162 It can be imagined how ineffective such a truncated investigatory authority, shorn of the sanction of compulsory process, has been. As our Supreme Court has put it, "Experience has taught that inere requests for ... information which is volunteered is not always accurate or complete; so some means of compulsion are essential to obtain what is needed." "163

Legislative committees in France, dependent solely on volunteered information, have been notoriously ineffective. In 1934, a high French Government official was reported to have said to a witness who was to appear before an inquiry committee, "Do you really still pay attention to parliamentary investigations? That's all vanished with yesteryear's snows." 184

The major weakness of French legislative committees has been their inability to assert an effective right to scrutimize administrative files and records. Very often, French committees have had to complain of that "ad-

16112 Corbett, Paritamentary History 693 (1812).

162 Quoted in Ehrmann, The Duty of Disclosure in Parliamentary Investigation: A Comparative Study, 11 U. Car. I. REv. 1, 6 (1943).

103 McGrain v. Daugherty, 273 U.S. 135, 175 (1927).

164 Quoted in Ehrmann, The Duty of Disclosure in Parliamentary Investigation: A Comparative Study, 11 U. CHI. L. REv. I, 148 (1943). 
mirable solidarity of the ministries that induces the nondelivery of documents which are almost always believed to be secret and confidential."105

The result has been that the French Parliament has had no effective investigatory power, and this has, without a doubt, played its part in the general dechine of republican institutions in France. Thus, to take an outstanding example, when the famous Stavisky affair arose in the early 1930 's, there was no effective investigatory power to uncover a scandal which all but undermined the French constitutional system. In the words of one commentator, ". . . when, a year later, the Stavisky affair came into the open, the president of the committee complained that if he had obtained 'judicial' powers for his inquiry in 1933, it might have been possible to uncover in time a scandal which almost cost the life of republican institutions in France."108

The same writer makes the following observation about the ineffectiveness of legislative committees in France:

The unsatisfactory results in ... France ... can easily be explained by the insufficient powers obtained by the parliamentary committees. Investigations which were barred from the cognizance of pertinent facts by the reluctance of witnesses or of the executive were bound to lead nowhere .... Moreover, a procedure which was helpless against a witness who chose to insult the investigating committee hardly increased respect for parliamentary institutions, and therefore could not be relied upon to strengthen popular belief in effective democratic government. ${ }^{107}$

The pertinency of the French experience has been pointed out by Judge Wyzanski:

Congressional mvestigations are only one, if an extreme example of our belief that exposure is the surest guard not only against official corruption and bureaucratic waste, mefficiency and rigidity but against private malpractices, divisive movements and antisocial tendencies in the body politic. That this confidence in legislative investigations as a prophylactic is not absurd is demonstrated to some extent by the difference in the strength and survival quality of democracy in English-speaking countries where such investigations are encouraged and Continental countries where they have been lield within close bounds .... Perhaps France would have been better off if the Stavisky scandal liad been investigated ratler than hushed up. ${ }^{168}$

The French experience provides a striking example of what may happen when legislative investigatory powers are frustrated. It provides a lesson which our Congress should well consider before allowing its own powers of inquiry to become atrophied.

165 See $i d$. at 139 .

166 Id. at 25.

167 Id. at 151-52.

168 Wyzanski, Standards for Congressional Investigations, 3 N.Y. Ass'N OF BAR RECORD 93, 101-02 (1948), quoted in TaYLor, Grand Inquest 179 (1955). 
It is important to remember that the problems posed by the presentday growth of executive power are not entirely without precedent in our law. It is basically those problems with which the common-law world had to deal in Tudor and Stuart times. At that time also the powers of the executive were being increased to a hitherto unprecedented degree and the jurisdiction of the ordinary courts was being superseded by a host of executive tribunals, of which the most important were the Star Chamber and Chancery.

Then, too, it was the legislature that had to assume a primary responsibility for preserving the rule of law. The parallel of Stuart times is most suggestive. We, too, are confronted with the constant aggrandizement of executive authority and the need to impose safeguards, if the rule of law is to be maintained as the dominant characteristic of our policy. The answer which our predecessors gave to the question of how to curb executive power is one which we can scarcely afford to ignore. The legislators of Stuart times met and mastered their problems of admimistrative law by restraiming executive pretensions and insuring that all departments and agencies were wholly subject to legislative control. Can the Congress today do less than to seek to follow their example?

How can this be done, however, if the Congress and its committees are not to have unrestricted access to all information within government agencies? "To deny Congress power to acquaint itself with facts is equivalent to requiring it to prescribe remedies in darkness."169

The executive tendency to withhold information is, without a doubt, one of the critical problems of present-day public law. The time has not yet come in the Anglo-American world when deliberate official misuse of the privilege of secrecy is rife. But the vast extension of executive authority presents an ever larger scope for the claim of privilege. "Indeed it requires no great flight of imagination to realize that if the Government's contentions in these cases were affirmed the privilege agamst disclosure might gradually be enlarged by executive determinations until, as is the case in some nations today, it embraced the whole range of governmental activities." "The possibibities of . . . abuse are plamly latent in this privilege. There is needed only the willingness to exercise them. ${ }^{171}$

In the moving words of a federal court: "We need to recall in this connection the words of Edward Livingston: 'No Nation ever yet found any inconvenience from too close an inspection into the conduct of its officers, but many have been brought to ruin, and reduced to slavery, by suffering

109 Landis, Constitutional Limitations on the Congressional Power of Investigation, 40 HaRv. L. REv. 153, 209 (1926).

170 Reynolds v. United States, 192 F.2d 987, 995 (3d Cir. 1951).

1718 WiGMORE, EvideATCE 791 (3d ed. 1940). 
gradual imposition and abuses, which were imperceptible, only because the means of publicity had not been secured.' And it was Patrick Henry who said that 'to cover with the veil of secrecy the common routine of busmess, is an abomination in the eyes of every intelligent man and every friend to his country." "172 